\title{
Exploitation, trade and farming of palm weevil grubs in Cameroon
}

Fogoh John Muafor

Aurèle Ayemele Gnetegha

Philippe Le Gall

Patrice Levang



\title{
Exploitation, Trade and Farming of Palm Weevil Grubs in Cameroon
}

\author{
Fogoh John Muafor \\ Living Forest Trust (LIFT) \\ Ministry of Forestry and Wildlife (MINFOF) \\ Aurèle Ayemele Gnetegha \\ University of Dschang \\ Living Forest Trust (LIFT) \\ Philippe Le Gall \\ Institut de recherche pour le développement (IRD) \\ Patrice Levang \\ Institut de recherche pour le développement (IRD) \\ Center for International Forestry Research (CIFOR)
}


Working Paper 178

(c) 2015 Center for International Forestry Research

(c) (i) Content in this publication is licensed under a Creative Commons Attribution 4.0 International

(CC BY 4.0), http://creativecommons.org/licenses/by/4.0/

ISBN 978-602-1504-97-0

DOI: http://dx.doi.org/10.17528/cifor/005626

Fogoh John Muafor, Aurèle Ayemele Gnetegha, Philippe Le Gall and Patrice Levang. 2015. Exploitation, trade and farming of palm weevil grubs in Cameroon. Working Paper 178. Bogor, Indonesia: CIFOR.

Cover photo by Jean Grégoire Kayoum (IRD)

All photos by Fogoh John Muafor

CIFOR

Jl. CIFOR, Situ Gede

Bogor Barat 16115

Indonesia

$\mathrm{T}+62(251) 8622-622$

$\mathrm{F}+62(251) 8622-100$

E cifor@cgiar.org

\section{cifor.org}

We would like to thank all donors who supported this research through their contributions to the CGIAR Fund. For a list of Fund donors please see: https://www.cgiarfund.org/FundDonors

Any views expressed in this publication are those of the authors. They do not necessarily represent the views of CIFOR, the editors, the authors' institutions, the financial sponsors or the reviewers. 


\section{Contents}

Abbreviations $\quad$ vi

Acknowledgments

Summary $\quad$ viii

1 Introduction 1

1.1 Background 1

1.2 Objectives of the study 2

1.3 Benefits of the project 2

2 Forest insects as a source of food in Cameroon 3

2.1 Edible insects 3

2.2 Species of African palm weevil 4

2.3 Areas where palm beetle grubs are exploited 5

2.4 Development of palm beetle grubs on host plant species 6

2.5 The palm weevil grub businesses in Cameroon 6

3 Nutrient value of palm weevil grubs 8

4 Methodology 10

$\begin{array}{lll}4.1 \text { Study area } & 10\end{array}$

4.2 Field methods 11

4.3 Data analysis
15

5 Results and discussion 16

5.1 Indigenous methods of grub exploitation 16

5.2 Contribution of palm weevil grubs to livelihoods 21

5.3 Environmental impacts of indigenous harvesting methods 24

5.4 Grub marketing chain 25

5.5 Grub farming method and productivity of food formulas 26

5.6 Comparison of the production, physiological characteristics and palatability of grubs from the $\begin{array}{ll}\text { indigenous harvesting and farming systems } & 27\end{array}$

6 Conclusion and recommendations 30

7 References 31 


\section{List of figures, tables and photos}

\section{Figures}

1 Area of Cameroon where palm weevil larvae are consumed (south of Adamaoua). 5

2 Locations of the study areas. 10

3 Comparison of the daily productivity of grubs by stem harvesting method. 20

4 Comparison of grub exploitation with other economic activities in the study areas. 22

5 Popularity of grubs compared to bushmeat. 23

6 Local perceptions of grub exploitation and trading. 23

7 Distribution of grub exploiters by age.

8 Market chain for palm beetle grubs. 25

9 Comparison of the per-kilogram prices of grubs and other sources of protein. 26

10 Number of grubs produced per food formula. 27

11 Variation of grub production with the level of freshness of raffia tissue. 27

12 Comparison of grub productivity per stem of raffia exploited in the different production systems. 28

\section{Tables}

1 Families of edible insects cited in literature for Cameroon. 3

2 Insects currently eaten in the humid forest zones of Cameroon. 4

3 Consumption and sale of caterpillars and weevil grubs in southern Cameroon. 6

4 Approximate nutrient content of palm weevil grubs. 8

5 Comparison of the amino acid profile of palm weevil grubs and egg ( $\mathrm{mg} / \mathrm{g}$ protein).

6 Comparison of essential amino acids in palm weevil grubs to reference values. 9

7 Mineral composition of palm weevil grubs $(\mathrm{mg} / 100 \mathrm{~g})$.

8 Total number of households sampled per village. 12

9 Advantages and disadvantages of the two indigenous harvesting systems. 20

10 Daily production of grubs by harvesting system. 20

11 Period of grub harvest. 21

12 Socioeconomic importance of grubs by villages. 21

13 Medicinal value of grubs in the study area. 21

14 Importance of grubs for household income. 22

15 Distribution of grub collectors by gender.

16 Distribution of respondents by marital status and village. 24

17 Number of raffia stems felled per plot. 25

18 Physiological characteristics and palatability of wild and farmed grubs. 29

\section{Photos}

1 Adult African palm weevils (Rhynchophorus phoenicis). 4

2 Larvae (grubs) of the African palm weevil. 4

3 Small-scale traders of palm weevil grubs in Cameroon markets. $\quad 7$

4 Local assistants participating in field data collection. 11

5 Interviews using semi-structured questionnaires (left) and a focus group discussion (right). 11

6 Survey of indigenous harvesting processes in a swampy raffia ecosystem. 12

7 Evaluation of the productivity of raffia stems.

8 Weighing grubs collected from the wild. 13

9 Experimental hut (left) and trial farming of grubs in wooden boxes (right). 14

10 Installation of experimental grub farming apparatus. 14

11 Coupling of adult palm weevils before introducing them into experimental boxes. 15 
12 A stem of a felled oil palm tree (left) and a stem of young raffia colonized by grubs (right).

13 Collecting grubs from naturally infested raffia stems.

14 A leaf of zam with thorns (left) and essa without thorns (right).

15 Felling of raffia stems for grub production in the semi-farming system.

16 Incision of felled raffia stem (left) and covering the stem with raffia leaves (right). 18

17 Removal of raffia leaves from the incision on the stem of felled raffia. 18

18 Listening for grubs (left) and splitting open the raffia trunk (right). 19

19 Removal grubs by hand in the semi-farming system.

20 Extraction of grubs from infested young raffia palms using the traditional gathering method. 24

21 Destruction of raffia ecosystems in the semi-farming method. 25

22 Sales of grubs in an urban market (left) and at roadsides in villages (right). 26

23 Harvesting of grubs from the experimental farming system. 27

24 An unidentified species of grub parasite. 28

25 Preparation of farmed grubs for sampling. 


\section{Abbreviations}

CIFOR Center for International Forestry Research

EAA essential amino acids

FAO

Food and Agricultural Organization of the United Nations

LIFT

Living Forest Trust

MINFOF

Ministry of Forestry and Wildlife

NTFPs

non-timber forest products

WHO

World Health Organization

XAF

Central African CAF Franc 


\section{Acknowledgments}

We are thankful to the people of Obout, Ebomssi II, Ntoung I, Ntoung II, Ndjibe, Djodjok and Nyimbe villages for their hospitality, support and active participation in this research. We would also like to acknowledge the valuable contributions of the field assistants who worked on the field data collection. 


\section{Summary}

The larvae (grubs) of the African palm weevil (Rhynchophorus phoenicis Fabricius, 1801) are consumed by the majority of the inhabitants of the Congo Basin. Studies of their biochemistry indicate that they are extremely rich in essential food nutrients; they contain proteins, carbohydrates, fats and energy values comparable to that of beef and fish. They are particularly rich in essential amino acids such as lysine, valine, leucine, isoleucine, phenylalanine, threonine and methionine. They are also an excellent source of minerals such as sodium, magnesium, manganese, calcium, potassium and iron. The exploitation and trade of weevil grubs is an important source of income for most forest dependent communities in Cameroon and the Congo Basin. Palm beetle grubs are currently harvested only from raffia and palm stems in the wild and their availability is linked to seasonal variations. The supply of grubs from the wild is irregular and can't satisfy the increasing demand for this product while indigenous harvesting methods are unsustainable.

As raffia ecosystems are under threat and weevil grubs can provide an alternative food and income source through community-based forest management in Cameroon, a project was jointly implemented by the Living Forest Trust (LIFT), the Center for International Forestry Research (CIFOR) and Institut de Recherche pour le Développement (IRD) to study the sustainability of indigenous harvesting methods and trade in grubs, and to find ways to farm these insect resources. The study was conducted using a participatory research approach and by establishing an experimental grub farming scheme in which different food formulas were tested. Seven villages situated in the Center and East regions of Cameroon were selected and surveyed for a period of one year. The study was carried out in two phases: August 2013 to February 2014 and July 2014 to November 2014.
The results of this study show that two indigenous methods (traditional grub gathering and grub semifarming) were used to exploit grubs in Cameroon. Of the two regions studied, traditional collection was practiced in both the Center and East regions, while the semi-farming method was common in the Center region (especially around the Obout area). Globally, grub exploitation and trade represented $21 \%$ of all economic activities (agriculture, fishing, hunting, etc.) in the villages studied. The average monthly income generated by professional grub collectors varied between XAF 90,000 (USD 180) and XAF 300,000 (USD 600), representing 30 to $75 \%$ of their household income. However, indigenous harvesting methods proved to be less productive, irregular, unsustainable and involved the destruction of raffia ecosystems.

To address this situation, a grub farming system was established during the course of this study. This system involves collecting, coupling and introducing adult palm weevils in boxes containing fresh raffia tissues. It was estimated that the production of grubs in this farming system would take 30 days. For 3 females introduced, up to 73 grubs were harvested from boxes containing the preferred food formula (an average of $69 \pm 5.6$ ). This productivity is higher than the quantity of larvae harvested from a single stem of raffia $(35 \pm 13.2$ and $50 \pm 10.1)$ using traditional grub gathering and semi-farming systems, respectively. The farming system guarantees the sustainability of the raffia ecosystem as it requires the use of small quantities of raffia tissue (less than a quarter of the quantity of raffia used in the semifarming system). This farming system can be used in the production of grubs at any time of the year, thereby providing an opportunity for a continous year-round production of these nutrient-rich insects, while securing their place as an important protein and income source in Cameroon. 


\section{Introduction}

\subsection{Background}

Food security remains one of the most fundamental challenges for human welfare and economic growth in most African countries, since sufficient food to meet the needs of all citizens is not available at the national level (Benson 2004). Despite the fact that the Central African subregion is classified as an important agricultural basin, many people in this area are unable to acquire and effectively utilize the food they need for a healthy life. Even in Cameroon, where agriculture and animal husbandry are mostly practiced in the subregion, many cases of food insufficiency have been recorded in recent years, especially in the northern part of the country where climatic conditions are less favorable. This lack of food and high poverty rates have led to both rural and unprivileged urban communities becoming increasingly dependent on the forest for their livelihoods. Unfortunately, the increased dependence on forest landscapes and resources is an important driver of deforestation, biodiversity erosion and climate change. The quest to satisfy household protein needs in rural areas is a major cause of biodiversity erosion and ecosystem conversion. More than half of the population in Cameroon and the Congo Basin live in rural areas and depend on bushmeat to satisfy their daily protein needs. Annual bushmeat consumption in this area is estimated to be between 1 to 3.4 million tonnes $(\mathrm{t}$ ) per year (Wilkie and Carpenter 1999), with 60\% of species harvested at unsustainable rates, constituting a grave threat to biodiversity conservation ( $\mathrm{Fa}$ et al. 2002).

Many measures have been envisaged to reduce the problems of food insufficiency and biodiversity erosion in Cameroon and the Congo Basin, such as agricultural intensification, improved food processing and the production of alternative food resources. The need to promote the use of nontimber forest products (NTFPs) in particular as an alternative for improving livelihoods, while reducing human pressure on biodiversity has largely been acknowledged. Accordingly, many NTFPs have been identified as beneficial, amongst which are those of plant origin (Ndoye et al. 1997; Arnold and Ruiz Pérez 2001; Belcher et al. 2005), bushmeat (Asibey and Child 1991; Wilkie and Carpenter 1999) and forest insects (FAO 1995; De Foliart 1997; Stack et al. 2003; Vantomme et al. 2004; Muafor et al. 2012, 2014). Of the different NTFPs, edible insects are amongst the most abundant and easily renewable forest resources. Some edible insects are very rich in proteins, fat and energy values, while others are rich sources of important vitamins and minerals (Dreyer and Wehmeyer 1982). Compared to beef and fish, insects have almost the same proportion of proteins, fat and energy value (Malaisse 1997). They are also rich in vitamins such as vitamin B1, vitamin B12 and vitamin $\mathrm{B} 6$ as well as mineral salts, especially iron and calcium (De Foliart 1992). Research has shown that $100 \mathrm{~g}$ of cooked insects provides more than $100 \%$ of the daily requirements of the vitamins and minerals they contain (De Foliart 1992).

Regarding their advantages, edible insects can effectively serve as a substitute to meat and fish in periods of availability. Concerns are rising over the need to optimize the potential of insect resources as an alternative in the development of food and feed, as well as to develop insect mini-livestock farming systems. Currently, the establishment of small insectbased food and feed enterprises is more developed in Asia than in Africa where entomophagy is equally high. However, in developing countries like those of the Congo Basin where it is relatively easy to bring insects to the market, and where demand for edible insects is high, the establishment of insectbased enterprises and the processing of insects into street foods and animal feed could easily be achieved if people were trained in insect production and processing methods (Van Huis et al. 2013).

The main groups of insects that can easily be targeted for industrial production in the Congo Basin are those that have been popular for human nutrition. Such species include: caterpillars, palm beetle grubs, termites, crickets, grasshoppers and locusts (FAO 1995; De Foliart 1997; Stack et al. 2003; Vantomme et al. 2004). The larvae of the African palm weevil Rhynchophorus phoenicis (Fabricius, 1801) is particularly significant, as they are extremely rich in essential food nutrients and are consumed and traded across the entire Congo Basin region. The larvae are harvested by systematically extracting them from the trunks of raffia or palms. However, the exploitation 
of these resources from the wild is unsustainable, irregular and doesn't satisfy increasing market demand. There have been a number of studies on the contribution of grubs to rural livelihoods in the Congo Basin (FAO 1995; De Foliart 1997; Dounias 1999; Stack et al. 2003; Vantomme et al. 2004).

Although some of these studies recommend the need to domesticate grubs as a solution to the problem of seasonal irregularity, insufficiency and sustainability, no attempt to farm the insects has ever been made. The lack of interest in the domestication of this species is principally due to a lack of appropriate farming methods.

In order to find ways to produce large quantities of grubs while sustaining the raffia ecosystem, a project was jointly implemented by the Living Forest Trust (LIFT), the Center for International Forestry Research (CIFOR) and Institut de Recherche pour le Développement (IRD) to study the sustainaibility of indigenous harvesting methods and trade of weevil grubs, as well as develop a farming method that could be used for the production of grubs in an outdoor situation. In a practical manner, this study provided answers to the following questions:

- What are the indigenous methods of grub exploitation and their effects on raffia ecosystems?

- What is the contribution of palm weevil grubs to food and household income?

- What quantities of grubs are harvested per trunk and per harvesting period?

- What farming method can be used for the production of palm grubs?

- Is there any difference in the physiology and palatability of farm bred weevil grubs and those obtained from the wild?

\subsection{Objectives of the study}

The overall objective of this study is to contribute to livelihood improvement and the enhancement of community-based conservation through the sustainable and continuous production of African palm weevil grubs (Rynchophorus phoenicis). Specifically, the study aims to:

- study indigenous methods of grub exploitation in the Centre and East regions of Cameroon;

- evaluate the contribution of palm weevil grub to livelihoods in the targeted regions;

- determine the impacts of indigenous grubs harvesting methods on raffia ecosystems;

- analyze the grub marketing chain;

- establish a method for the domestication of palm beetle grubs;

- compare the productivity, physiological characteristics and palatability of grubs from indigenous harvesting and farming methods.

\subsection{Benefits of the project}

In addition to information on the socioeconomic importance of indigenous harvesting practices, this study provides first-hand information on a method for the farming of palm weevil grubs. Results obtained could be used for the promotion of sustainable and continuous production of palm weevil grubs. This will ensure increased productivity and year-round availability of these resources, thereby providing increased opportunity for alternative protein sources in the study area. By providing the opportunity for villagers to increase their protein and income sources, this study is expected to contribute to efforts to find solutions to the major problems of poverty, food insecurity and biodiversity erosion in the area. In addition, the adoption of the grub farming method in local communities will considerably reduce the number of raffia palms that are felled for the production of grubs. The results are also a base for future studies that can lead to the development of appropriate methods for the processing, packaging and large scale commercialization of this nutritious 'free' resource. 


\section{Forest insects as a source of food in Cameroon}

\subsection{Edible insects}

Foods hunted and gathered from forests contribute to food security by providing people with calories, animal and plant proteins, essential minerals and micronutrients (Pimentel et al. 1997). It is largely accepted that food forest products can complement household agricultural production in periods of crisis. Moreover, forest food products are essential for livelihoods, especially in the Congo Basin where over $90 \%$ of people depend on natural resources for food, medicine and income generation (COMIFAC 2008). The gathering of insects for food in particular is a very old practice in the Congo Basin region. From the literature, 45 insect species in 16 families have always been popular as human food in Cameroon (Table 1).

However, today the Acrididae, Pyrgomorphidae, Mantidae, Thespidae, Cetoniidae, Buprestidae, Rutelinae, Formicidae, Saturniidae are only consumed in the northern part of Cameroon. In this region, grasshoppers (Orthoptera) and termites (Isoptera) are important delicacies (Seignobos et al. 1996).
Conversely, in the humid forest and savannah zones of Cameroon (south of Adamawa), most of the edible insect species cited in the literature are no longer part of the human diet. This decline can be explained by: the high levels of rural dependence on bushmeat; the proliferation of churches (that forbid the consumption of insects); and the adoption of Western feeding habits. However, due to increasing levels of food-related diseases (e.g. cancer, obesity, diabetes and hypertension), poverty, food shortages and the quest for environmental sustainability, many southern Cameroonians are reintegrating insects into their daily diets. But in southern Cameroon, this is limited to only eight families of insects (Table 2).

Palm weevil grubs, caterpillars, termites and locusts are the most commonly consumed insects. Apart from palm weevil grubs that are available year-round in variable quantities, all the other species occur at different times of year. However, the identification of Cameroon's edible insects is still problematic and little is known about the taxonomy of the different species.

Table 1. Families of edible insects cited in literature for Cameroon.

\begin{tabular}{lcll}
\hline Family & Number of species & Stage of consumption & Source \\
\hline Curculionidae & 1 & Larval and adult & Bodenheimer (1951) \\
Dynastidae & 1 & Larval and adult & Tessmann (1913) \\
Scarabaeidae & 1 & Adult & De Lisle (1944) \\
Cetoniidae & 1 & Adult & Seignobos et al. (1996) \\
Buprestidae & 1 & Adult & Seignobos et al. (1996) \\
Rutelinae & 1 & Adult & Bodenheimer (1951) \\
Formicidae & 2 & Larval and adult & Van Huis (2003) \\
Saturniidae & 2 & Larval & Malaisse (1997) \\
Notodontidae & 1 & Larval & Merle (1958) \\
Acrididae & 28 & Adult & Barreteau (1999) \\
Pyrgomorphidae & 2 & Adult & Barreteau (1999) \\
Gryllidae & 1 & Adult & Grimaldi and Bikia (1985) \\
Mantidae & 1 & Adult & Barreteau (1999) \\
Thespidae & 1 & Adult & Barreteau (1999) \\
Macrotermitidae & 2 & Adult & Bodenheimer (1951) \\
Hemiptera & 1 & Adult & Seignobos et al. (1996) \\
\hline
\end{tabular}


Table 2. Insects currently eaten in the humid forest zones of Cameroon.

\begin{tabular}{llll}
\hline Order & Family & Common name & Stage of consumption \\
\hline Coleoptera & Curculionidae & Palm weevil grub & Larval \\
& Dynastidae & Scarab beetle & Larval and adult \\
Lepidoptea & Saturniidae & Caterpillar & Larval \\
& Notodontidae & Caterpillar & Larval \\
Orthoptera & Acrididae & Locust & Adult \\
& Pyrgomorphidae & Grasshopper & Adult \\
& Gryllidae & Cricket & Adult \\
Isoptera & Macrotermitidae & Termite & Adult \\
\hline
\end{tabular}

\subsection{Species of African palm weevil}

The African palm weevil is a species of the genus Rhynchophorus, which belongs to the family Curculionidae, commonly called snout beetles and known to be one of the most diversified groups of


insects in the world. Adult members of this family have a snout-like projection of their mandibles called a rostrum (Photo 1). These modified mouthparts are used for feeding and to make holes in host plant material where eggs are laid. The larvae (or grubs) have relatively large mandibles and are legless (Photo 2).

Photo 1. Adult African palm weevils (Rhynchophorus phoenicis).

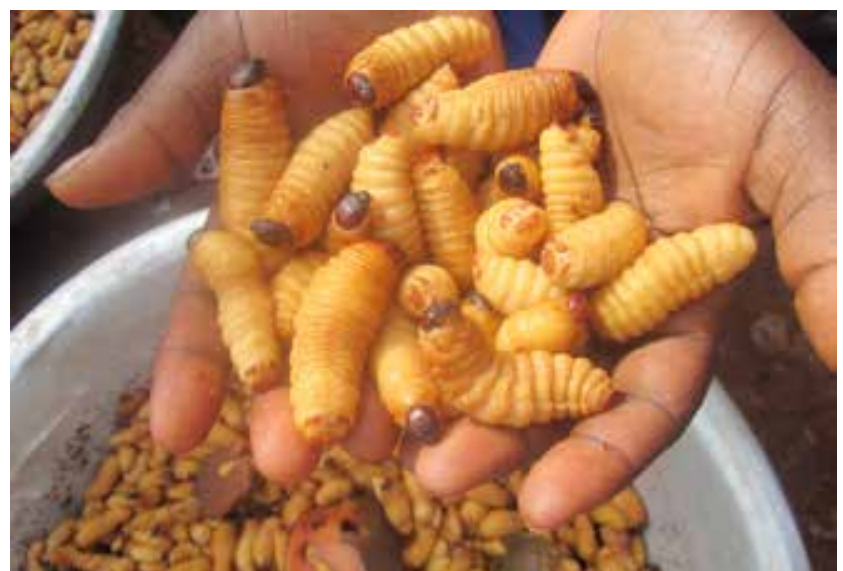

Photo 2. Larvae (grubs) of the African palm weevil. 
In Cameroon, there is little knowledge about the diversity of this genus. However, there is speculation that Cameroon harbors many species of Rhynchophorus, with the most popular being Rhynchophorus phoenicis (Fabricius 1801) and Rhynchophorus quadrangulus (Quedenfeldt 1888). Rhynchophorus quadrangulus is adapted to highland areas and occurs within the humid mountain ranges of the Cameroon volcanic belt (Southwest, West and Northwest regions of Cameroon), while Rhynchophorus phoenicis is more common in the humid lowland forest and savannah areas of the country.

\subsection{Areas where palm beetle grubs are exploited}

This genus has been recorded across tropical Africa (Tambe et al. 2013), where it feeds mainly on oil palm (Elaaeis guineensis Jacq.), date palm (Phoenix dactylifera L.), raffia palm (Raphia spp.) and coconut palm (Cocos nucifera L.) (Gries et al. 1993). The larvae are important pests of these plant species, due to their boring action into plant stems, which causes yellowing of the leaves (Mariau et al. 1981). In Cameroon, these insects are exploited for consumption and trade in seven of the ten regions of Cameroon (notably the East, South, Centre, Littoral, Southwest, West and Northwest regions). These regions cover the entire humid part of the country south of Adamaoua (Figure 1).

The larvae have different names in different areas of the country. They are commonly called fos by the Beti communities of the Centre and South regions, mbé in the Yemba dialect (Dschang) in the West, poseh by the Baka and the Bagando communities in the East and tumbu or tumbu for palm tree in Pidgin English that is commonly used by the English speaking communities of the Southwest and Northwest regions of the country. These larvae are highly sought after for food in most parts of Cameroon today; they are even offered as a special dish in important ceremonies and top restaurants in some urban cities in the South and Centre regions of the country. Together with caterpillars, grubs are largely accepted for consumption in the forest regions of Cameroon. Balinga (2003) studied the contribution of these two insects to food security in Cameroon, and reported that palm weevil grubs are more commonly consumed and traded than caterpillars by many tribes in southern Cameroon (Table 3).



Figure 1. Area of Cameroon where palm weevil larvae are consumed (south of Adamaoua). 
Table 3. Consumption and sale of caterpillars and weevil grubs in southern Cameroon.

\begin{tabular}{|c|c|c|c|}
\hline Regions & Caterpillars & Weevil grubs & Sale status \\
\hline West & Not consumed & Consumed by all tribes & No trade of caterpillars and larvae \\
\hline Northwest & $\begin{array}{l}\text { Consumed by the Meta and Bali } \\
\text { tribes }\end{array}$ & Consumed by all tribes & No trade of caterpillars and larvae \\
\hline Southwest & Consumed by the Bakundu tribe & Consumed by all tribes & $\begin{array}{l}\text { No trade of caterpillars and trade } \\
\text { of larvae }\end{array}$ \\
\hline Centre & $\begin{array}{l}\text { Consumed by certain Beti tribes and } \\
\text { many non-natives }\end{array}$ & Consumed by all tribes & $\begin{array}{l}\text { Trade of caterpillars (seasonal) and } \\
\text { larvae }\end{array}$ \\
\hline Littoral & $\begin{array}{l}\text { Consumed by certain Mbo tribes } \\
\text { and non-natives }\end{array}$ & Consumed by all tribes & Trade of caterpillars or larvae \\
\hline South & Consumed by certain Beti tribes & Consumed by all tribes & $\begin{array}{l}\text { No trade of caterpillars and trade } \\
\text { of larvae }\end{array}$ \\
\hline East & Consumed by all tribes & Consumed by all tribes & Trade of caterpillars and larvae \\
\hline
\end{tabular}

Source: Balinga (2003)

The productivity of these grubs in the western highland region (West, Southwest and Northwest) of Cameroon is very low. Conversely, the Centre, South and East regions are favorable areas for their production, due to the presence of vast raffia ecosystems. The Nyong Basin is particularly productive and constitutes the main production site for weevil grubs sold in cities such as Yaoundé, Douala and Ebolowa.

\subsection{Development of palm beetle grubs on host plant species}

The larvae are harvested by systematically extracting them from the trunks of oil palms (Elaaeis guineensis Jacq.) when the palms have been cut down for palm wine production or from the trunks of dead or wounded raffia palms (Raphia spp.) growing densely in swamps. Wounded raffia trunks produce sap, which attracts adult weevils. Once on the plant, female weevils mate with males. The females deposit eggs on the decaying parts of the trunks, and they develop into young larvae within a week. These larvae develop over four weeks into mature larvae that can be harvested. The quantities harvested from oil palm are generally less than from raffia palm. In the case of raffia, harvesters risk insect and snake bites to spend hours or days in dark, muddy waters in order to obtain large quantities. Dead raffia stems are split open with machetes or axes and grubs are picked off by hand.

\subsection{The palm weevil grub businesses in Cameroon}

Palm weevil grubs are particularly important economic resources in Cameroon. They provide complementary income for many rural people who depend on the palm weevil trade as their main or part-time activity. From the dense, humid, semideciduous forest zone in the east to the highland savannah in the west, this insect is traded (cooked or uncooked) by small-scale roadside vendors. Some markets in urban cities are renowned for the sale of palm weevil grubs, such as Mvog-mbi, Mvog-ada and Nkondongo markets in Yaoundé, Bertoua main market, Abong-Mbang market, Ayous market and Mbalmayo market (Photo 3).

In these markets, palm beetle grubs are traded at all times of the year, though they are more abundant during the dry season. Between 25 and 30 individual insects are sold as one item in markets. A single glassfull of this insect costs XAF 500 (USD 1) in rural markets in smaller towns such as Abong-Mbang. This same glass-full is sold in big cities such as Yaoundé and Douala for XAF 1500 (USD 3) in times of abundance and XAF 2500 (USD 5) in periods of scarcity. Brochettes of prepared grubs are sold for XAF 100 (USD 0.2) per brochette and contain 3 or 4 palm weevil grubs. Transborder trade is equally visible, as some grubs are exported to neighboring countries such as Equatorial Guinea, Gabon and Nigeria and even to European countries such as Belgium and France. 

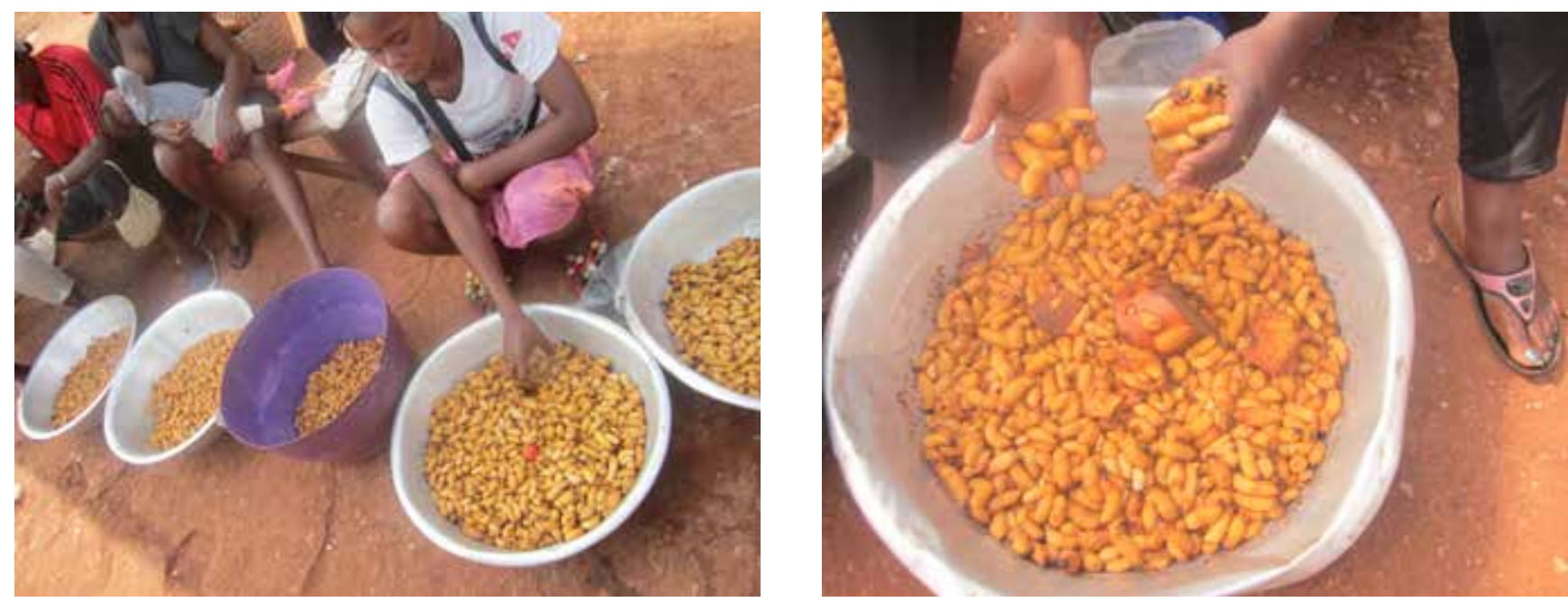

Photo 3. Small-scale traders of palm weevil grubs in Cameroon markets.

The palm weevil business involves a network of collectors, intermediate traders (bayam-sellam) and retailers. Each of these categories of traders derives important income from the sale of palm beetle grubs. Dounias in López and Shanley (2004) reported that the average monthly income for larvae harvesters in rural areas is about XAF 35,500 (USD 71), for live larvae sold to retailers supplying city markets and CTA 25,000 (USD 50) for roasted larvae sold in snack bars and along roadsides. He compared such income with other rural income sources and concluded that they were significantly higher than the monthly income obtained by unskilled workers in town, or by the rural producers of coffee (XAF 25,000 or USD 50) in good years. Compared with other NTFPs, he noted that the African palm weevil grub generates better monthly income than either bushmeat (XAF 29,000 or USD 58), Gnetum leaves (XAF 15,500 or USD 31) or rattan (XAF 13,000 or USD 26). 


\section{Nutrient value of palm weevil grubs}

Many studies on the biochemistry of palm weevil grubs have indicated that this insect is extremely rich in essential food nutrients. From studies conducted by Womeni et al. (2012), the nutrient content of these grubs is quite interesting (Table 4).

The moisture content of larvae is quite high, comparable to that of fish, meat and eggs. Such high moisture content implies that most of the essential nutrients in the larva will be in solution and in forms that are easily available to the body when the larva is consumed as food (Ekpo and Onigbinde 2005). According to Elemo et al. (2011), the lipid value ranges between $25.30 \%$ and $66.61 \%$. This oil extract is different to other animal oils/fat, as it is liquid at room temperature, probably due to the presence of unsaturated fatty acids such as oleic acid (C18:1) and linoleic acid (C18:2). An iodine value of 192.3 Wijs was observed, while the saponification value was observed to be $427.7 \mathrm{mg} \mathrm{KOH} / \mathrm{g}$ of oil. These values are relatively high when compared to those of lard and other plant oils (Pearson 1976).

In terms of protein, these grubs contain at least 18 known amino acids with almost all the essential amino acids (EAA). Most of the EAA including lysine, valine, leucine, isoleucine, phenylalanine, threonine and methionine, are contained in the larvae. EAA such as lysine and threonine which are normally deficient in grains and cereals have high concentrations in these grubs. Tyrosine and methionine are present in low concentrations in the

Table 4. Approximate nutrient content of palm weevil grubs.

\begin{tabular}{lcc}
\hline Component & \% Fresh weight & g/100 g dry weight \\
\hline Moisture & $61.85 \pm 0.2$ & - \\
Lipids & $25.30 \pm 0.22$ & $66.61 \pm 0.35$ \\
Proteins & $8.21 \pm 0.35$ & $21.06 \pm 0.22$ \\
Carbohydrates & $2.97 \pm 0.01$ & $7.63 \pm 0.12$ \\
Energy (Kcal) & 684.81 & 714.25 \\
\hline
\end{tabular}

Source: Womeni et al. (2012). larvae. Womeni et al. (2012) in Table 5 compared the amino acid profile of these grubs with a conventional food (chicken egg).

Essential amino acids from grubs are superior to those from conventional foods (e.g. eggs). Ogbuagu et al. (2011) compared the essential amino acids of weevil grubs with reference values given by $\mathrm{FAO} /$ WHO (1973) and concluded that the content of some essential amino acids in the grubs were higher than the reference values (Table 6).

Palm weevil grubs are also rich in mineral composition. They have high values of sodium, magnesium, manganese, calcium, potassium and iron see (Table 7).

Table 5. Comparison of the amino acid profile of palm weevil grubs and egg ( $\mathrm{mg} / \mathrm{g}$ protein).

\begin{tabular}{lcc}
\hline Amino acid & Palm weevil grubs & Egg \\
\hline Aspartic acid & 104.41 & 82.20 \\
Glutamic acid & 155.05 & 121.30 \\
Serine & 41.23 & 67.20 \\
Glycine & 39.68 & 30.20 \\
Histidine & 24.00 & 20.90 \\
Arginine & 34.44 & 57.00 \\
Threonine & 23.91 & 44.70 \\
Alanine & 54.96 & 50.30 \\
Proline & 64.00 & 33.80 \\
Tyrosine & 25.15 & 38.10 \\
Valine & 27.64 & 54.20 \\
Methionine & 22.97 & 28.10 \\
Tryptophane and & not evaluated & $17.2 \&$ \\
Cysteine & & 19.00 \\
Isoleucine & 67.33 & 48.80 \\
Leucine & 96.02 & 81.10 \\
Phenylalanine & 31.59 & 48.20 \\
Lysine & 54.84 & 65.90 \\
\hline
\end{tabular}

Source: Womeni et al. (2012) 
Table 6. Comparison of essential amino acids in palm weevil grubs to reference values.

\begin{tabular}{lcc}
\hline Amino acid & Composition & $\begin{array}{c}\text { FAO/WHO (1991) } \\
\text { Ref value }\end{array}$ \\
\hline $\begin{array}{l}\text { Lysine } \\
\text { Methionine }+\end{array}$ & 8.32 & 5.8 \\
Cysteine & 2.30 & 2.5 \\
Threonine & 3.47 & 3.4 \\
Tryptophan & ND & 1.0 \\
Valine & 4.50 & 3.5 \\
Leucine & 8.04 & 6.6 \\
Isoleucine & 3.73 & 2.8 \\
Phenylalanine + & 8.62 & 6.3 \\
Tyrosine & & - \\
Arginine & 6.47 & - \\
Histidine & 3.51 & \\
\hline
\end{tabular}

Source: Ogbuagu et al. (2011)
Table 7. Mineral composition of palm weevil grubs (mg/100 g).

\begin{tabular}{lc}
\hline Mineral & Recorded value \\
\hline $\mathrm{Fe}$ & $65.23 \pm 0.15$ \\
$\mathrm{Zn}$ & $10.57 \pm 0.89$ \\
$\mathrm{Mn}$ & $1.16 \pm 0.09$ \\
$\mathrm{~Pb}$ & $0.21 \pm 0.08$ \\
$\mathrm{Cd}$ & $0.039 \pm 0.022$ \\
$\mathrm{Mg}$ & $127.16 \pm 5.13$ \\
$\mathrm{Ca}$ & $60.81 \pm 0.32$ \\
$\mathrm{Cu}$ & $1.26 \pm 0.04$ \\
$\mathrm{Na}$ & $773.49 \pm 1.02$ \\
$\mathrm{~K}$ & $26.65 \pm 0.24$ \\
\hline
\end{tabular}

$\mathrm{NB}$ : Values represent the mean \pm SEM of three estimations Source: Ekpo and Onigbinde (2005). 


\section{Methodology}

\subsection{Study area}

The study was conducted in the Mbalmayo and Abong-Mbang divisions, in the Centre and East regions of Cameroon respectively. The first study site extends across the Obout and Ebomssi II villages in the Mbalmayo division, while the second site covered Ntoung I, Ntoung II, Ndjibe, Djodjok and Nyimbe villages in the Upper Nyong division (Figure 2).

These two sites fall within the River Nyong Basin, which is known to be one of the most fragmented landscapes in the Congo Basin forest. The area is highly fragmented by pressure arising from diverse human activities, such as uncontrolled timber exploitation, small-scale subsistence farming and urbanization. As a result of this increasing anthropic pressure, land, water, forest and other related resources in the basin are endangered (Jiofack 2010).

The climate of these areas is a wet equatorial type (Guinea climate type), with high temperatures $\left(24^{\circ} \mathrm{C}\right.$ on average). Humidity and cloud cover are relatively high, and precipitation averages 1500-2000 $\mathrm{mm}$ per year, spread over four seasons: a long, dry season from December to May, a light, wet season from May to June, a short, dry season from July to October, and a heavy, wet season from October to November. A greater part of the area is covered by swampy ecosystems, most of which are dominated

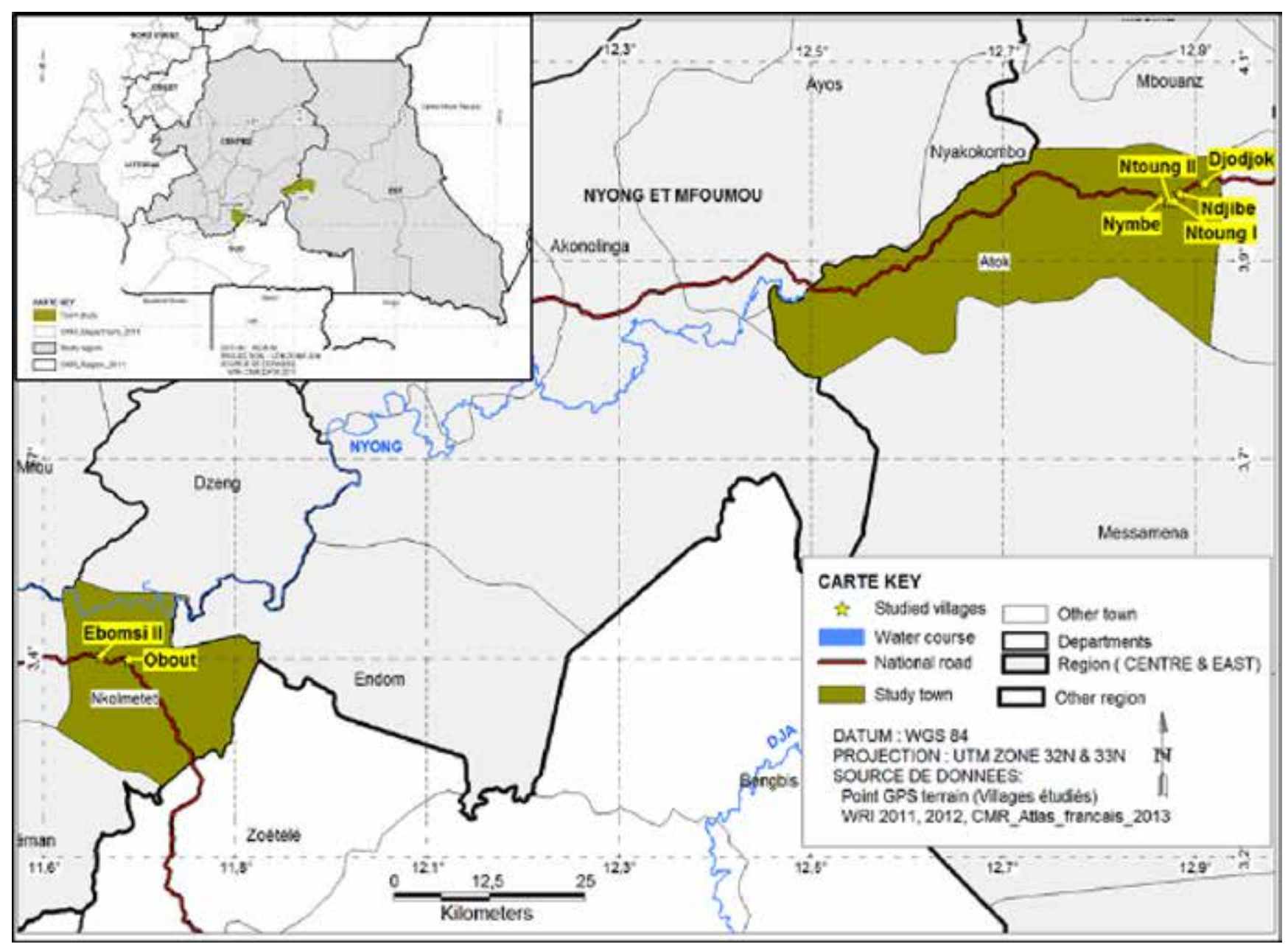

Figure 2. Locations of the study areas. 
by raffia species, Sterculia subviolacea and Macaranga asas. Due to human influence, the forest cover is less intact and alternates with a mosaic of fields, fallow land secondary forest and logged-over forest. Sometimes, dense secondary forest, marshy forest, ripicole forest and savannah riparian forest were recorded at various sites. However, dense forest is dominated by hardwood species, some of which grow to heights exceeding $70 \mathrm{~m}$, such as ayous (Triplochyton scleroxylon), sapelli (Entandrophagma cylindricum), fraké (Terminalia superba), tali (Erytrophleum ivorense), kotibé (Nesogordia papaverifera), kossipo (Entandrophragma candolei), dibetou (Lovoa trichilioides), padouk rouge (Pterocarpus soyauxii), eyong (Eribloma oblogum) and diana (Celtis zenkeri) grow to heights in excess of $70 \mathrm{~m}$.

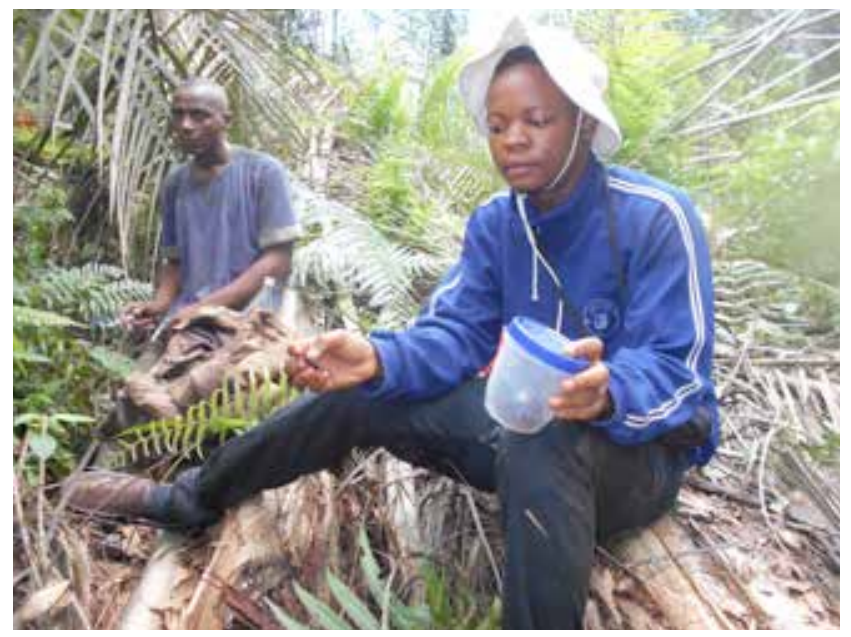

\subsection{Field methods}

Data was collected throughout the course of this study using a variety of social science methods, harvesting practices and an experimental breeding trial system. In each of the villages studied, local assistants were recruited to assist in field data collection (Photo 4).

\subsubsection{Methods used}

In order to obtain information on the indigenous exploitation of grubs, surveys were conducted using semi-structured questionnaires, focus groups and field observations (Photo 5). Questions focused on the quantities of grubs harvested, harvesting methods, marketing networks, contribution to livelihoods and

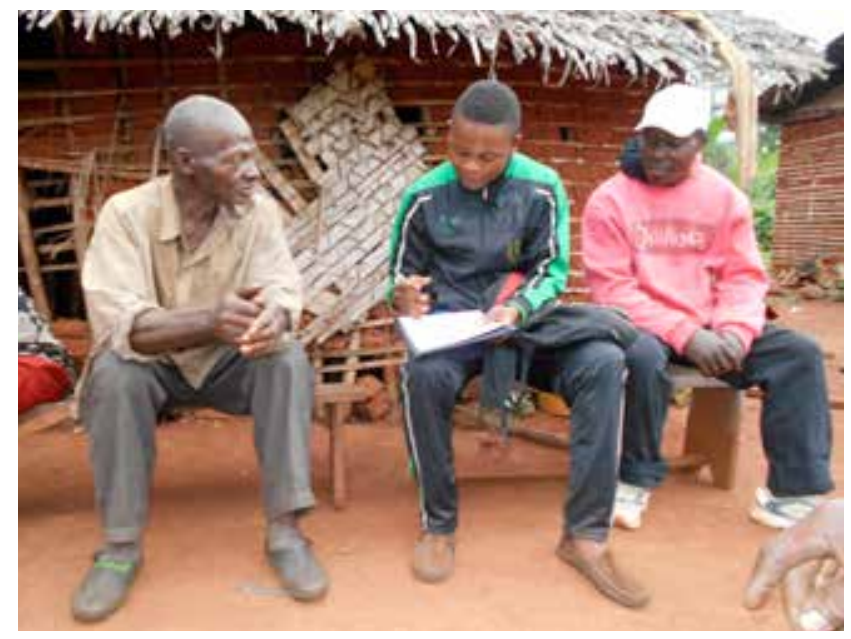

Photo 4. Local assistants participating in field data collection.


Photo 5. Interviews using semi-structured questionnaires (left) and a focus group discussion (right). 
other aspects of the management of grub resources. Interviews were conducted in 103 households, representing $30.3 \%$ of total households in the study area. In each of the households, key informants were mainly men, women and youth above 18 years of age.

The number of informants interviewed was different from one village to the other, based on the population size of the village. The lowest number of households surveyed was in Ebomsi II and the highest was in Nymbe (Table 8).
Focus groups permitted open discussions with villagers on different aspects of indigenous exploitation and trade in palm weevil grubs. At least two focus groups were organized in each of the eight villages.

\subsubsection{Participation in harvesting practices}

In addition to interviews in the villages, surveys were done in the swampy raffia forest ecosystems to study the different stages of the indigenous harvesting process, as well as to evaluate the productivity and ecological impacts of harvesting (Photo 6).

Table 8. Total number of households sampled per village.

\begin{tabular}{lccc}
\hline Village & Total number of households & Number of households interviewed & Percentage interviewed (\%) \\
\hline Obout & 57 & 17 & 29.82 \\
Elende & 20 & 6 & 30.00 \\
Ebomsi II & 24 & 7 & 29.16 \\
Ntoung I & 77 & 23 & 29.87 \\
Ntoung II & 34 & 10 & 29.41 \\
Ndjibe & 34 & 10 & 29.41 \\
Djodjok & 64 & 19 & 29.69 \\
Nymbe & 30 & 11 & 36.67 \\
Total & 340 & 103 & 30.29
\end{tabular}


Photo 6. Survey of indigenous harvesting processes in a swampy raffia ecosystem. 



Photo 7. Evaluation of the productivity of raffia stems.


Photo 8. Weighing grubs collected from the wild.

Harvesting was observed and collectors were interviewed at each stage of the process. The ecological impacts of indigenous harvesting practices in the Obout area were evaluated by counting the number of raffia stems destroyed within an area of $2500 \mathrm{~m}^{2}$. A total of four sample plots of $50 \mathrm{~m} \mathrm{x} 50 \mathrm{~m}$ each were created in the swampy forest. All the raffia stems that were cut down in the $2500 \mathrm{~m}^{2}$ area during the harvest period were counted. Such impacts were not assessed in the Ntoung area because grub exploitation there involves only systematic extraction from naturally infested raffia stems. The productivity

of the different harvesting systems was evaluated by counting the number of grubs harvested per stem of raffia exploited (Photo 7).

In order to determine the weight of grubs a collector can harvest per day, harvests were weighed on an electronic scale (Photo 8). The price of $1 \mathrm{~kg}$ of grubs was compared with that of other sources of protein such as beef and fish. The physiological characteristics of grubs from the different types of exploitation (wild or farmed) were determined by observing the color and size of grubs. 
Data on the palatability and physiological characteristics of farmed grubs were also collected using the above mentioned methods.

\subsubsection{Experimental grub farming system}

The experimental grub farming system was set up using plastic and wooden boxes $0.6 \mathrm{~m}$ long, $0.4 \mathrm{~m}$ wide and $0.4 \mathrm{~m}$ high. In the first phase of the experiment, wooden boxes were placed in an experimental hut, measuring $4 \mathrm{~m}$ long and $3 \mathrm{~m}$ wide, constructed in Ntoung village using materials such as wood, metallic grids and aluminum sheets (Photo 9).
Villagers helped us to construct this hut. Farming in wooden boxes was less successful (only 10 individuals were obtained in this trial); the second phase of the experimental farming was carried out in plastic boxes, which were suspended in an old hut in Obout village at a height of $1 \mathrm{~m}$ above the ground (Photo 10).

The boxes were suspended in the hut to avoid invasion by ants and other crawling invertebrates that could prey on the growing grubs. These boxes were filled with small quantities of four kinds of feed formula including: (i) only fresh tissues of young raffia stems, labeled OFRT; (ii) a mixture of $50 \%$


Photo 9. Experimental hut (left) and trial farming of grubs in wooden boxes (right).


Photo 10. Installation of experimental grub farming apparatus. 

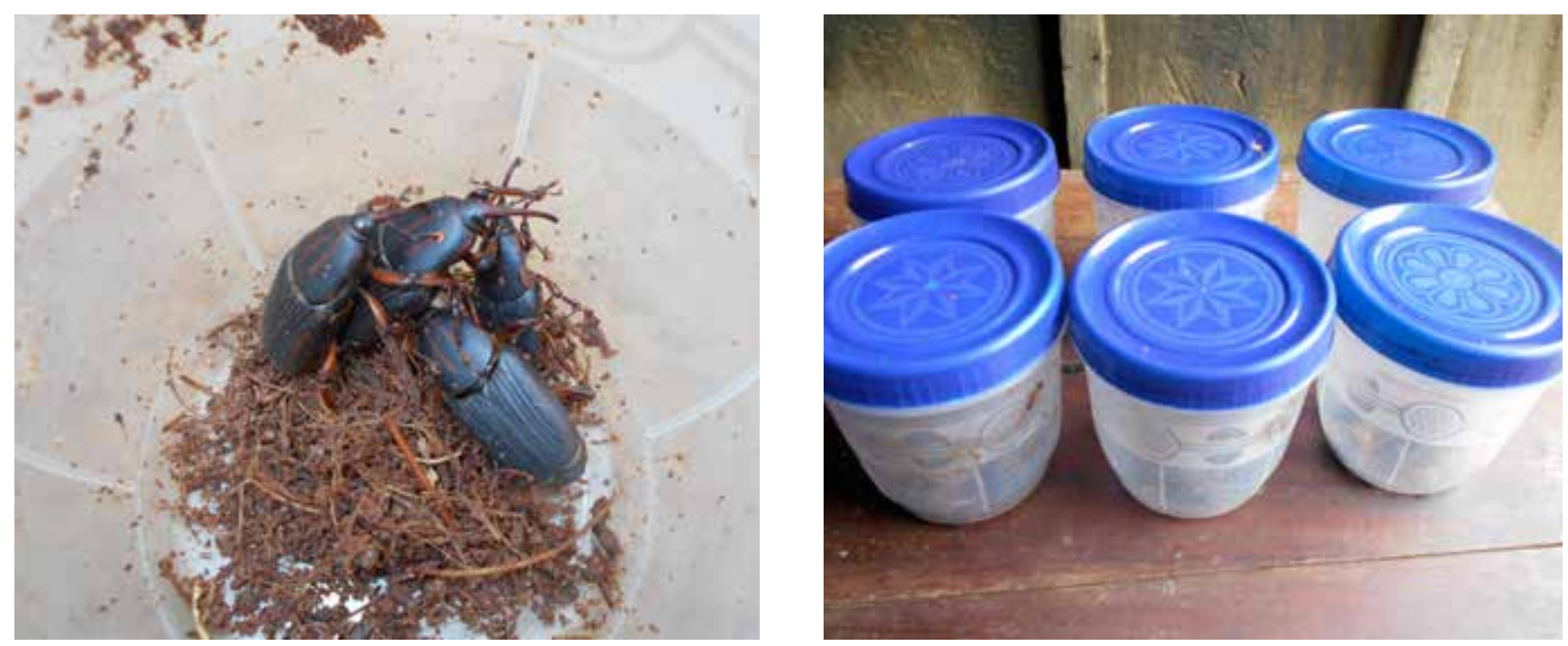

Photo 11. Coupling of adult palm weevils before introducing them into experimental boxes.

fresh and 50\% old (decayed) raffia tissues, labeled MFDRT1; (iii) a mixture of $75 \%$ fresh and $25 \%$ old raffia tissues, labeled MFDRT2; and (iv) only decayed or old raffia tissues, labeled ODRT. In total, the apparatus contained 2 boxes of OFRT, 1 box of MFDRT1, 1 box of MFDRT2 and 2 boxes of ODRT.

Individual female and male adult palm weevils were collected from the raffia stems by hand and coupled by placing them in closed, perforated small plastic cups for 48 hours before introducing them into the tubs containing the different food formulas (Photo 11). The rostrum of males is hairy and rough, while that of females is smooth and does not contain hairs.
A total of three couples of adult palm weevils were introduced to each box. The substrates (feed) in each of the boxes were enriched with newly harvested raffia tissues every 2 days to ensure good development of the grubs.

\subsection{Data analysis}

Data were computerized, treated and analyzed using Excel 2010. Quantitative analysis consisted of estimating percentages, mean values and standard deviations of variables. Results were presented in tables and graphs to facilitate interpretation. Statistical tests (ANOVA, T-test and correlation tests) were conducted using the statistical software $\mathrm{R}^{\oplus}$ version 3.0.0 to compare any differences. 


\section{Results and discussion}

\subsection{Indigenous methods of grub exploitation}

Traditional collection and semi-farming method were used to exploit palm weevil grubs.

\subsubsection{Traditional collection method}

Grubs were harvested by systematically extracting them from the trunks of oil palms when the palms had been cut down for palm wine production or from the trunks of raffia palms which were infested naturally by grubs in the swamps (Photo 12).

The quantity of grubs harvested from oil palm was lower than from raffia. In this system, collectors spent hours, and sometimes days, in raffia ecosystems to identify raffia stems that had been colonized by grubs. These raffia stems were uprooted and split open with machetes or axes to extract the grubs (Photo 13).

However, the identification of naturally infested or dead raffia stems required some expertise. This includes the detection of young raffia stems with slightly yellow juvenile leaves or dead adult raffia stems. In addition, collectors smelled the trunks and listened carefully for the noise produced in the trunks to detect the vibrations produced by nibbling grubs. According to Dounias, this method was

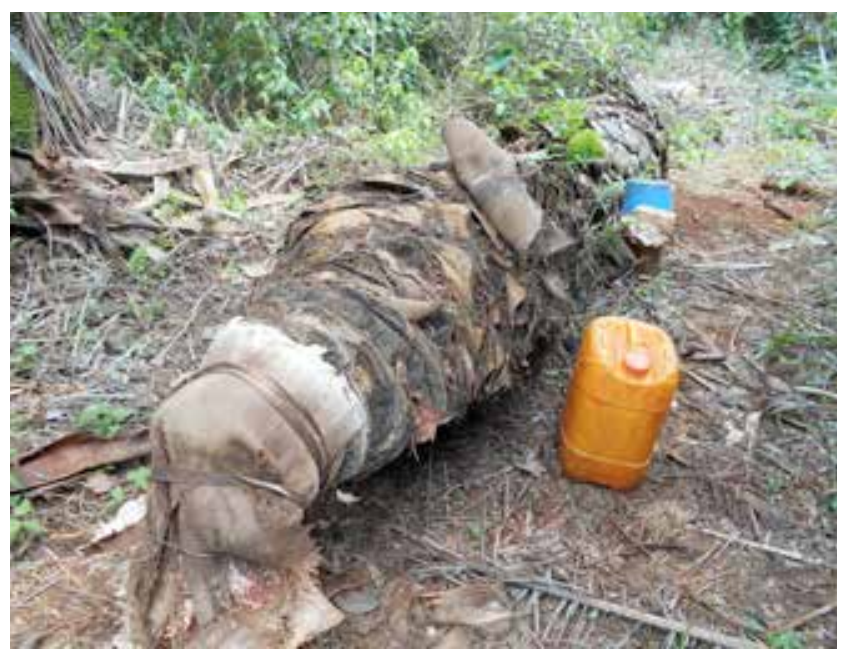

practiced by about six villages in southern Cameroon who specialize in the harvesting of larvae for trade. Such specialized collectors have developed specific harvesting tools and methods (Dounias 1999). This is the only method used for harvesting grubs in the Ntoung and Abong-Mbang areas.

\subsubsection{Semi-farming method}

This method has been developed and practiced in the Obout village area where the extraction and trade of palm weevil grubs is one of the main activities practiced by a large proportion of the populace. In this system, grub farmers begin the harvesting process by identifying the raffia that favors the development of grubs. In the Obout area, villagers have identified two types of raffia: essa and zam in the Ewondo dialect. Essa is exploited for weevil grubs while zam is used for wine production. Essa is exploited for the production of grubs in the Obout area. Although these two raffia species could not be identified taxonomically, some morphological differences were identified between the two species. Zam is characterized by stems grouped into small bunches of dense and tightly closed individuals; essa is made of single stems which are less dense. In addition, the leaves of zam are larger in size and are characterized by the presence of many thorns compared to those of essa (Photo 14).

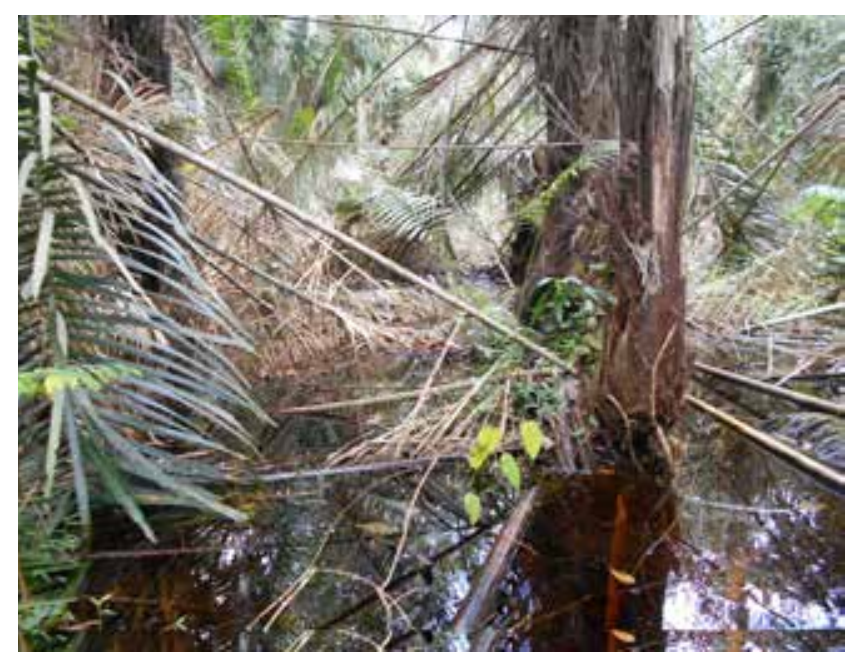

Photo 12. A stem of a felled oil palm tree (left) and a stem of young raffia colonized by grubs (right). 

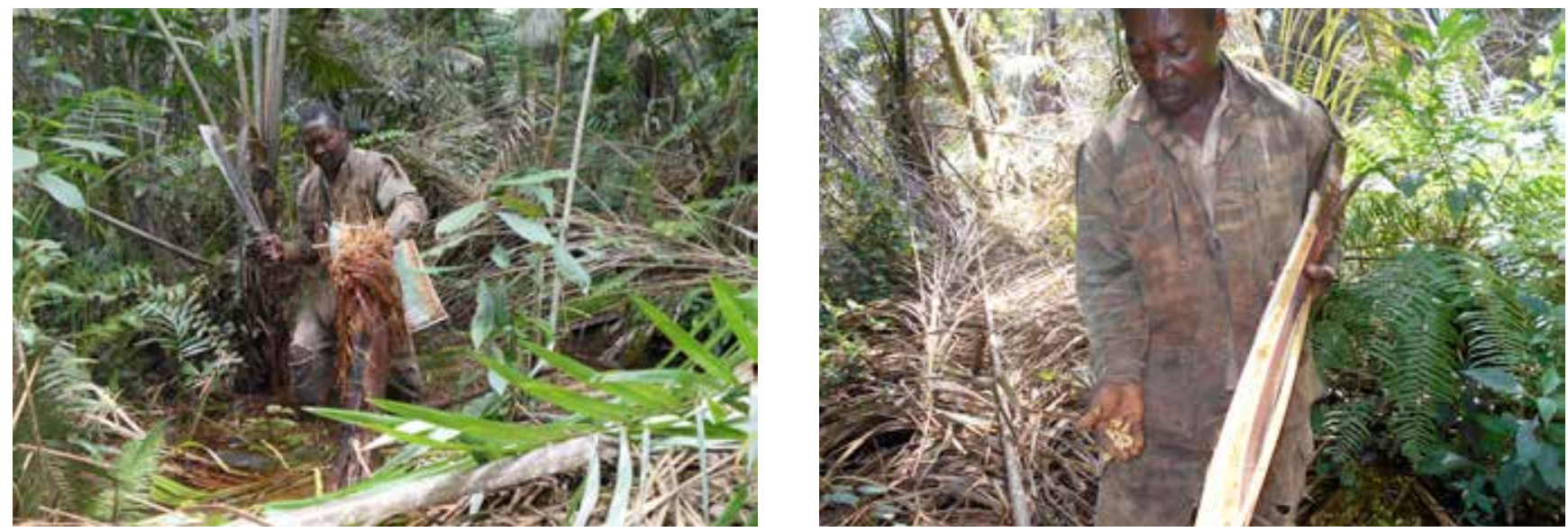

Photo 13. Collecting grubs from naturally infested raffia stems.
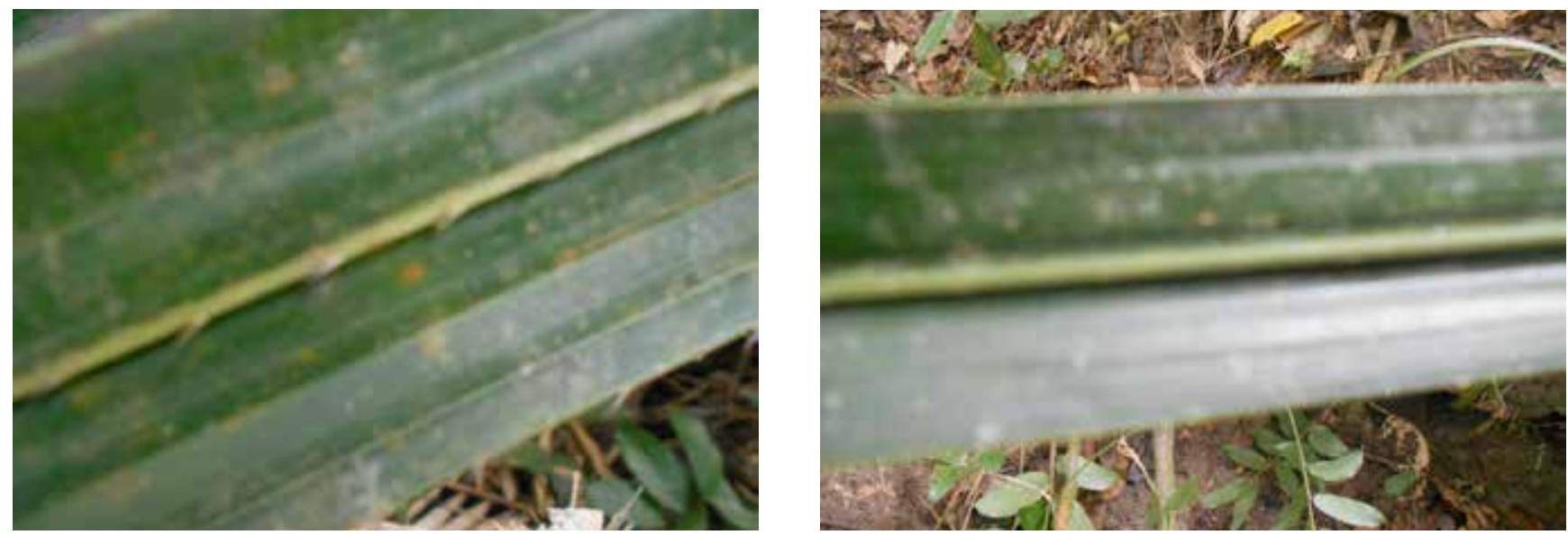

Photo 14. A leaf of zam with thorns (left) and essa without thorns (right).


Photo 15. Felling of raffia stems for grub production in the semi-farming system.

In the grub semi-farming process, mature stems of essa raffia are selected and cut down to facilitate their colonization by grubs (Photo 15).

Once the stem has been felled, an incision of 20 to $25 \mathrm{~cm}$ long and $5 \mathrm{~cm}$ deep is made on the trunk at about $1 \mathrm{~m}$ from the base of the crown. This incision is then covered with fresh raffia leaves to provide heat, and to prevent animals such as rats, squirrels and other predators consuming grubs (Photo 16). 
The stems are then allowed to decay for a period of 25 to 30 days, which gives enough time for the grubs to mature before harvest. The grubs develop inside the raffia stem and accelerate the decay of portions of the stem that have been colonized. The collection process begins by removing the leaves that covered the incision (Photo 17).

In order to determine if palm weevil grubs have colonized a raffia stem, the collector places his ear on the incision to listen for grubs nibbling the trunk. Once grubs are confirmed present in the trunk, the collector then proceeds to split the trunk (Photo 18).

The invaded raffia trunk is split open with an axe from the incision to about $60 \mathrm{~cm}$ towards the base and $40 \mathrm{~cm}$ to the apex of the trunk. This exposes the grubs for collection. However, the length of trunk split depends on the level of infestation. The productivity of trunks is affected significantly by the water level of the raffia ecosystem. Generally, trunks that are partly submerged are less productive. The grubs are hand picked off the stem one by one (Photo 19).

The productivity of raffia trunks varies between the two indigenous systems. A single trunk can produce an average of $35 \pm 13.2$ grubs by traditional gathering and $50 \pm 10.1$ grubs per trunk using the semi-farming method. With an average of $50 \pm$ 13.2 individuals, the productivity per stem of raffia is higher for the semi-farming system than for the traditional grub gathering method (Figure 3).
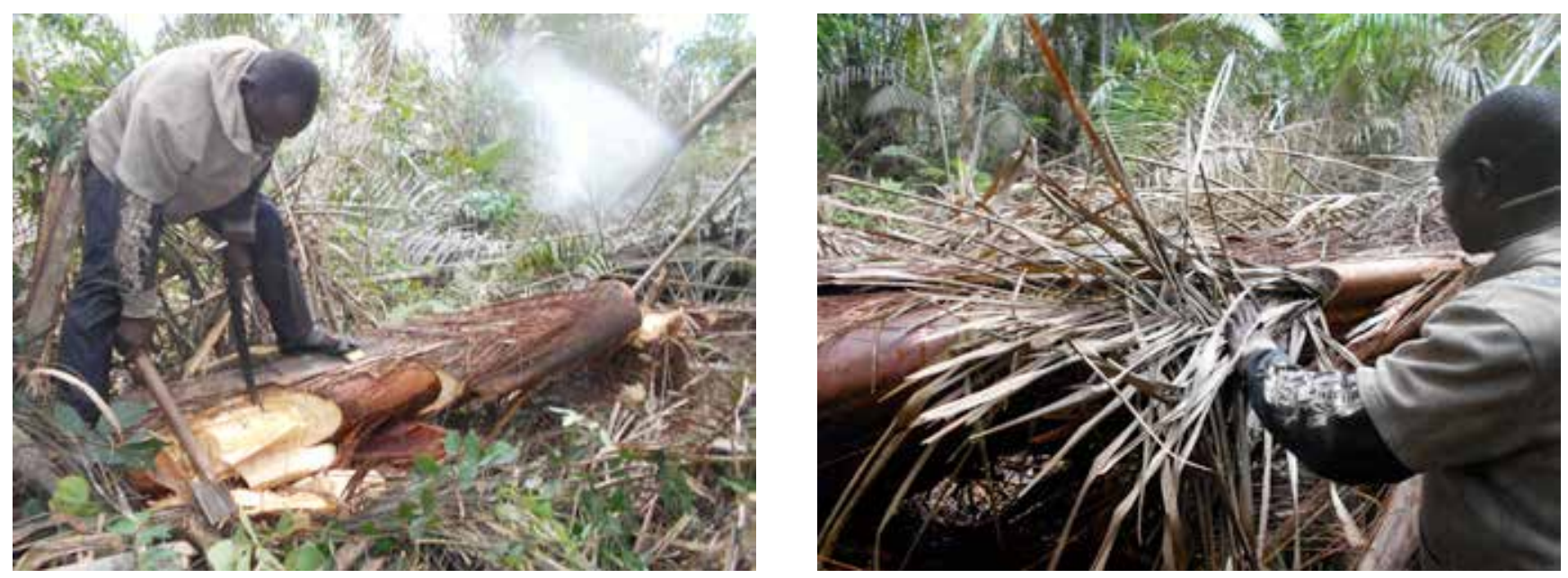

Photo 16. Incision of felled raffia stem (left) and covering the stem with raffia leaves (right).
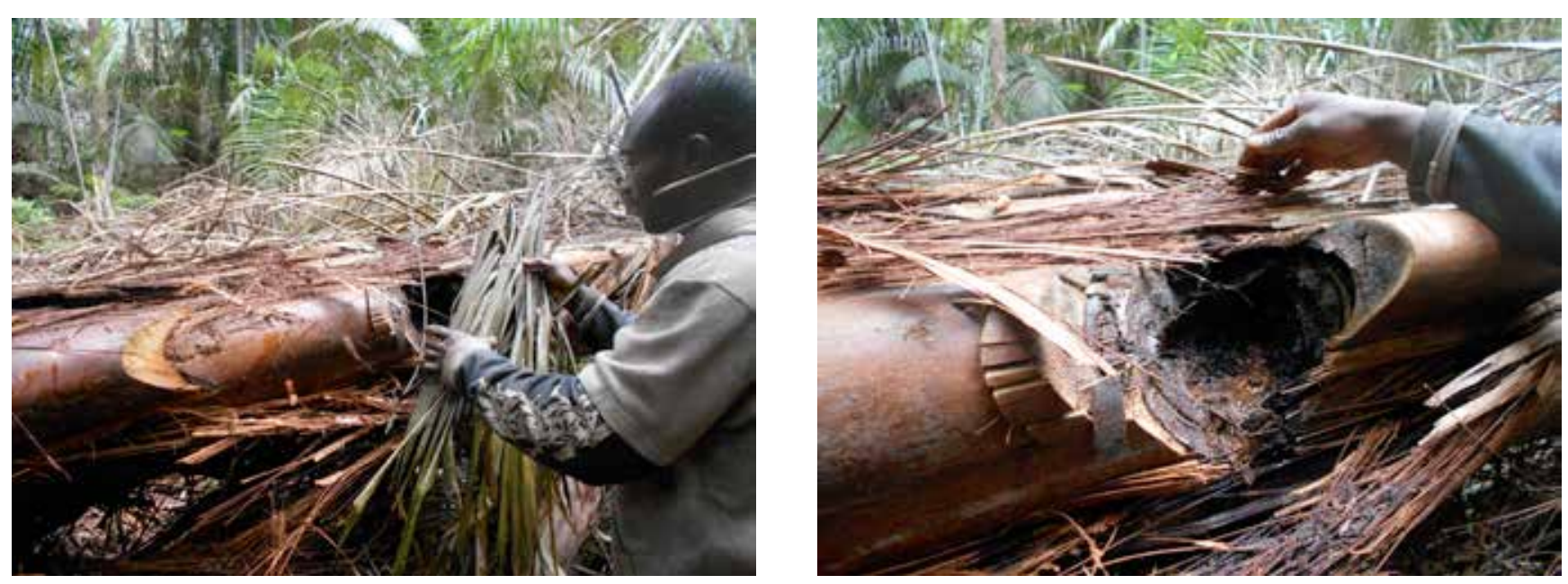

Photo 17. Removal of raffia leaves from the incision on the stem of felled raffia. 

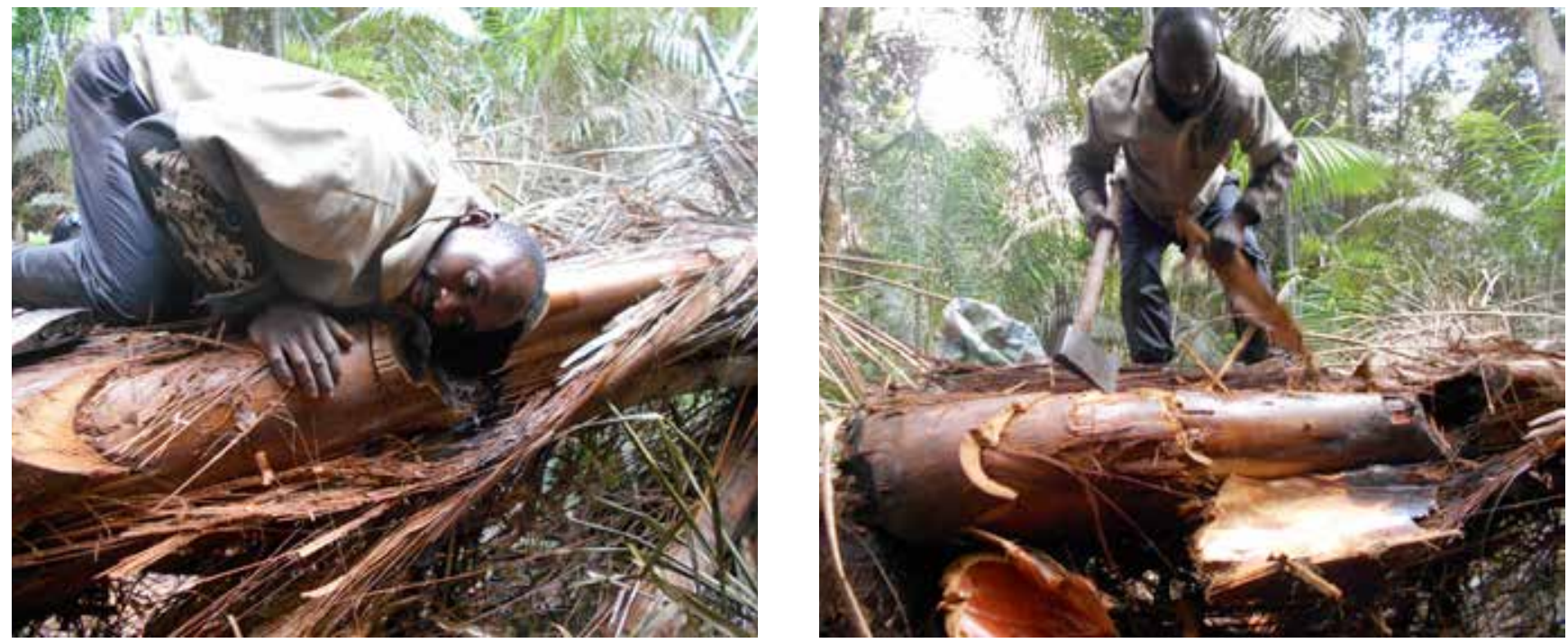

Photo 18. Listening for grubs (left) and splitting open the raffia trunk (right).
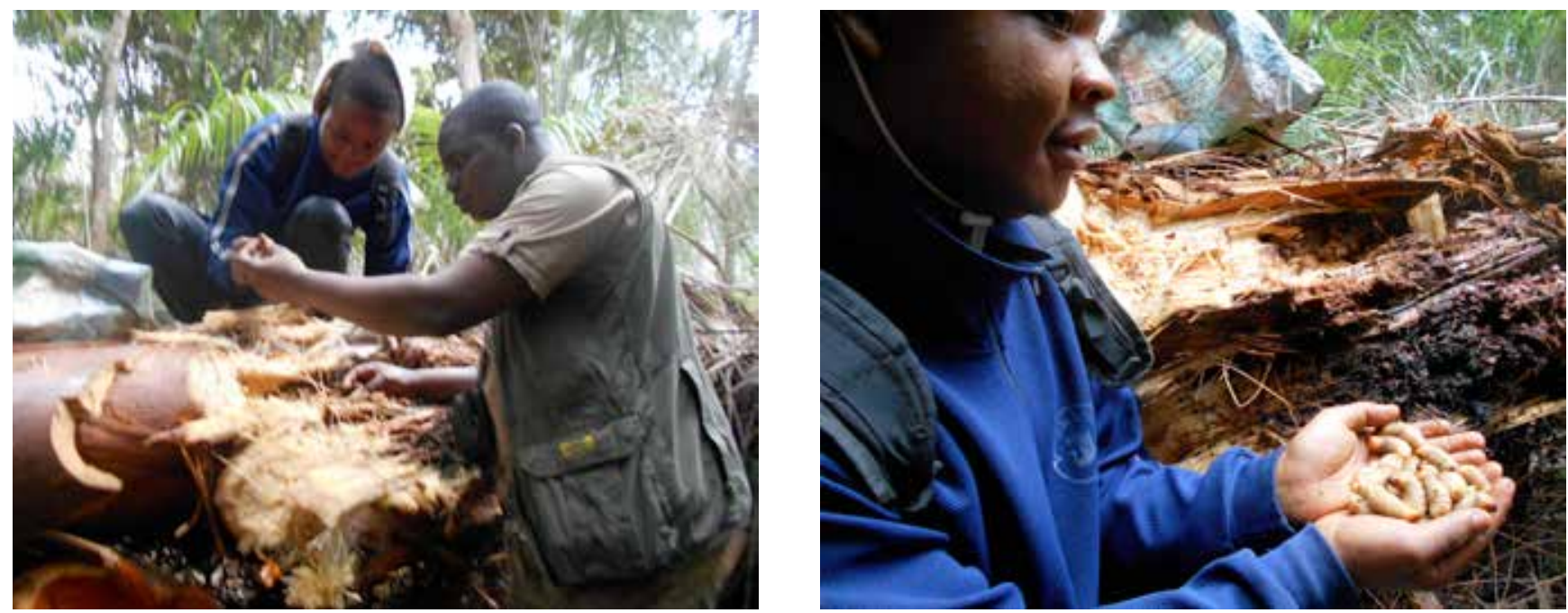

Photo 19. Removal of grubs by hand in the semi-farming system.

The difference observed in the productivity of the semi-farming and the traditional gathering methods is significant at a $95 \%$ confidence interval $(\mathrm{t}=$ $25.9808, \mathrm{df}=6, \mathrm{p}$-value $=2.144 \mathrm{e}-07)$. However, each of these indigenous harvesting methods has its advantages and disadvantages (Table 9).

\subsubsection{Average daily production for a single collector in the two harvesting systems}

The daily production of grubs varies from one collector to another, depending on whether they use the traditional grub gathering or the semi-farming method, as well as the number of raffia trunks they exploit in a day. In the semi-farming system, a single collector can harvest between 8 and 10 trunks per day, compared to 10 to 15 in the traditional gathering system. On average, daily grub production is higher in the Obout area - where the semi-farming system is practiced - than in the Ntoung area where traditional methods are used (Table 10).

From this table, it is clear that in order to produce 570 individuals (grub mass $5.3 \mathrm{~kg}$, valued at XAF 14,250 ), a total of 10 raffia stems are felled in the semi-farming system. Each raffia trunk can be exploited twice before it is abandoned. Most collectors exploit an average of 40 to 50 raffia stems per month. 


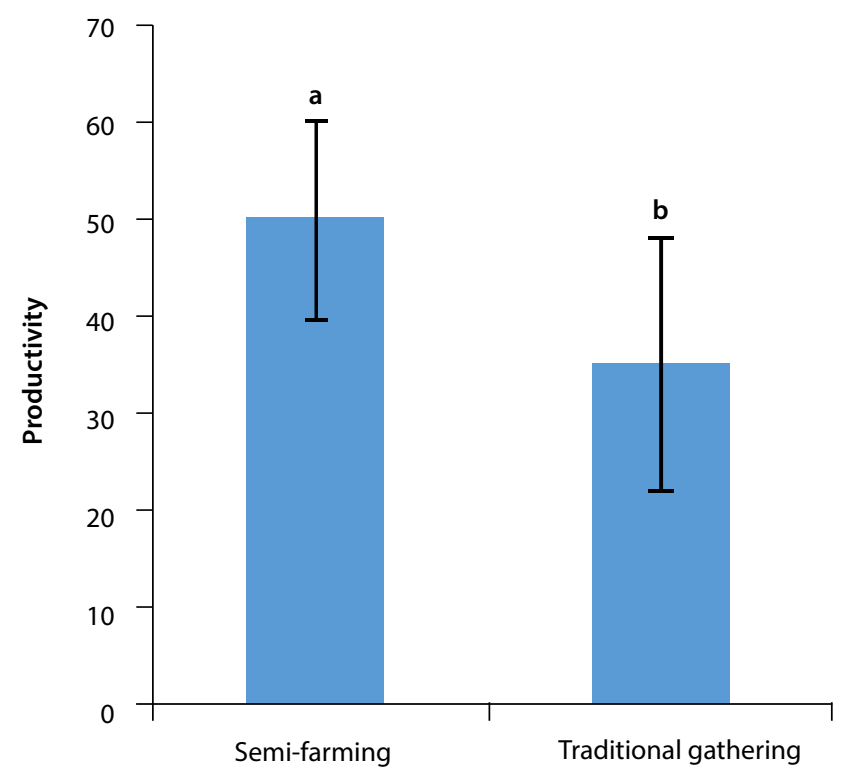

Harvesting technique

\subsubsection{Period of harvest}

In the Obout area, grubs are harvested from November to June, while in the Ntoung area harvesting takes place between October and March (Table 11).

The months of July, August, September and October are not good for the production of grubs in either area because of heavier rains during this period. These months are characterized by high rainfall and higher water levels in the raffia swamp ecosystem. The high water levels have a negative impact on the productivity of felled or dead raffia stems and cause access problems for collectors to the swamp forest; carnivorous or omnivorous fish species also consume the grubs during this time.

Figure 3. Comparison of the daily productivity of grubs by stem harvesting method.

Table 9. Advantages and disadvantages of the two indigenous harvesting systems.

\begin{tabular}{lll}
\hline & \multicolumn{2}{c}{ Indigenous systems } \\
\cline { 2 - 3 } Advantages & Semi-farming method & Traditional gathering \\
\hline & $\begin{array}{l}\text { Collectors do not spend days in the forest } \\
\text { during harvest }\end{array}$ & $\begin{array}{l}\text { More sustainable as only dead or infested raffia } \\
\text { stems are exploited } \\
\text { Drubs are sold in a fresher state, since sales are }\end{array}$ \\
& $\begin{array}{l}\text { Demands very little or no investment } \\
\text { carried out just a few hours after collection }\end{array}$ & $\begin{array}{l}\text { Demands less labor input and grubs are } \\
\text { collected as soon as the stem is cut down }\end{array}$ \\
& $\begin{array}{l}\text { Very destructive and unsustainable as it } \\
\text { involves the felling of thousands of raffia stems }\end{array}$ & $\begin{array}{l}\text { It is less productive and collectors must spend } \\
\text { days in the forest to collect adequate numbers } \\
\text { of grubs }\end{array}$ \\
& $\begin{array}{l}\text { More labor intensive and requires some } \\
\text { investment (e.g. hiring of assistants) to harvest } \\
\text { prepared trunks }\end{array}$ & $\begin{array}{l}\text { Some grubs might die after harvesting because } \\
\text { collectors stay longer in the forest. }\end{array}$ \\
\hline
\end{tabular}

Table 10. Daily production of grubs by harvesting system.

\begin{tabular}{llcccc}
\hline Village & Method of harvest & $\begin{array}{c}\text { Average number of } \\
\text { stems exploited }\end{array}$ & $\begin{array}{c}\text { Average daily Production } \\
\text { (individuals) }\end{array}$ & $\begin{array}{c}\text { Estimation } \\
\text { in kg }\end{array}$ & $\begin{array}{c}\text { Sales } \\
\text { (XAF) }\end{array}$ \\
\hline Obout & Semi-farming & 10 & 570 & 5.27 & 14,250 \\
Elende & Semi-farming & 8 & 496 & 4.58 & 12,400 \\
Ebomsi II & Semi-farming & 9 & 518 & 4.79 & 12,950 \\
Ntoung I & Traditional gathering & 15 & 418 & 3.86 & 10,450 \\
Ntoung II & Traditional gathering & 10 & 398 & 3.68 & 9,950 \\
Ndjibe & Traditional gathering & 12 & 395 & 3.75 & 9,875 \\
Djodjok & Traditional gathering & 12 & 410 & 3.79 & 10,250 \\
Nymbe & Traditional gathering & 13 & 389 & 3.59 & 9,725 \\
\hline
\end{tabular}


Table 11. Period of grub harvest.

\begin{tabular}{|c|c|c|c|c|c|c|c|c|c|c|c|c|}
\hline \multirow[t]{2}{*}{ Zone } & \multicolumn{12}{|c|}{ Months } \\
\hline & Jan & Feb & Mar & Apr & May & Jun & Jul & Aug & Sep & Oct & Nov & Dec \\
\hline Obout area & & & & & & & & & & & & \\
\hline Ntoung area & & & & & & & & & & & & \\
\hline
\end{tabular}

\subsection{Contribution of palm weevil grubs to livelihoods}

The exploitation and trade in palm weevils is an important source of livelihoods in both the Obout and Ntoung village areas. The exploitation of palm weevils is particularly important for securing or supplementing household food, income and medicinal sources (Table 12).

However, a greater proportion of the harvest is destined principally for trade and only individual grubs that fail to meet standard market criteria (injured, small-sized and dead specimens) are used for domestic consumption.

\subsubsection{The use of grubs as medicine}

The use of grubs as medicine in some of the villages, such as Obout, Elende, Ntoung I and Ntoung II dates back to the ancestral period. Although the level of local dependence on grubs for medicine has decreased in recent years, this resource is still important in the treatment of a number of ailments (Table 13).

\subsubsection{Contribution of the grub trade to household income}

The exploitation and trading of grubs is an important source of income for many households in all the villages in the study area. Monthly income generated by professional grub collectors from this activity varies between XAF 90,000 (USD 180) and XAF 300,000 (USD 600), while annual earnings reached XAF 2,400,000 (USD 4800) (Table 14).

During the harvest season income generated by professional grub collectors in Obout varies from XAF 1,600,000 (USD 3200) to XAF 2,400,000 (USD 4800). These incomes were higher than those observed from the exploitation of bushmeat (XAF $1,820,000$ or USD 3640) in villages around Lobeke National Park (Tieguhong and Zwolinski 2009). Income from grub trading is also significantly higher than the monthly income obtained by unskilled workers in town, or by the rural producers of coffee (XAF 25,000 or USD 50 in good years). Compared with other NTFPs, African palm weevil grubs generate more monthly income than bushmeat

Table 12. Socioeconomic importance of grubs by villages.

\begin{tabular}{lcccccccc}
\hline Uses & \multicolumn{8}{c}{ Villages } \\
\cline { 2 - 8 } & Obout & Elende & Ebomsi II & Ntoung I & Ntoung II & Ndjibe & Djodjok & Nymbe \\
\hline Food & $\mathrm{X}$ & $\mathrm{X}$ & $\mathrm{X}$ & $\mathrm{X}$ & $\mathrm{X}$ & $\mathrm{X}$ & $\mathrm{X}$ & $\mathrm{X}$ \\
Income & $\mathrm{X}$ & $\mathrm{X}$ & $\mathrm{X}$ & $\mathrm{X}$ & $\mathrm{X}$ & $\mathrm{X}$ & $\mathrm{X}$ & $\mathrm{X}$ \\
Medicine & $\mathrm{X}$ & $\mathrm{X}$ & & $\mathrm{X}$ & $\mathrm{X}$ & & & \\
\hline
\end{tabular}

Table 13. Medicinal value of grubs in the study area.

\begin{tabular}{llc}
\hline Medicinal value & Prophylaxis & $\begin{array}{c}\text { Percentage of } \\
\text { respondents (\%) }\end{array}$ \\
\hline Treatment of women's infertility & Eat oil extract with specific plant species (unidentified) & 24 \\
$\begin{array}{l}\text { Treatment of rashes and wounds } \\
\text { in children }\end{array}$ & $\begin{array}{l}\text { Apply a mixture of burned grubs, nest and grub oil extract } \\
\text { on the skin }\end{array}$ & 44 \\
Treatment of coughs and colds & Application of oil extract inside the nose & 9 \\
Fortification of children bone's & Consumption of pupae & 5 \\
\hline
\end{tabular}


Table 14. Importance of grubs for household income.

\begin{tabular}{|c|c|c|c|c|c|c|}
\hline \multirow[t]{2}{*}{ Villages } & \multicolumn{2}{|c|}{ Monthly income (XAF) } & \multicolumn{2}{|c|}{ Annual income (XAF) } & \multirow{2}{*}{$\begin{array}{l}\text { Number of } \\
\text { professional } \\
\text { grub collectors }\end{array}$} & \multirow{2}{*}{$\begin{array}{l}\text { Percentage } \\
\text { of household } \\
\text { annual income }\end{array}$} \\
\hline & $\begin{array}{l}\text { Minimum } \\
\text { value }\end{array}$ & $\begin{array}{c}\text { Maximum } \\
\text { value }\end{array}$ & $\begin{array}{l}\text { Minimum } \\
\text { value }\end{array}$ & $\begin{array}{l}\text { Maximum } \\
\text { value }\end{array}$ & & \\
\hline Obout & 200,000 & 300,000 & $1,600,000$ & $2,400,000$ & 17 & 65 to 75 \\
\hline Elende & 200,000 & 300,000 & $1,600,000$ & $2,400,000$ & 4 & 60 to 75 \\
\hline Ebomsi II & 180,000 & 300,000 & $1,440,000$ & $2,400,000$ & 3 & 50 to 75 \\
\hline Ntoung I & 100,000 & 240,000 & 600,000 & $1,440,000$ & 16 & 40 to 60 \\
\hline Ntoung II & 90,000 & 180,000 & 540,000 & $1,080,000$ & 7 & 40 to 50 \\
\hline Ndjibe & 120,000 & 150,000 & 720,000 & 900,000 & 4 & 30 to 40 \\
\hline Djodjok & 90,000 & 120,000 & 540,000 & 720,000 & 8 & 25 to 40 \\
\hline Nyimbe & 120,000 & 160,000 & 720,000 & 960,000 & 6 & 30 to 40 \\
\hline
\end{tabular}

NB: USD 1 = XAF 500

(XAF 29,000 or USD 58), Gnetum leaves (XAF 15,500 or USD 31) or rattan (XAF 13,000 or USD 26) as reported by Dounias in López and Shanley 2004).

Nonetheless, the contribution of this sector to household income is less than $40 \%$ in villages such as Ndjiebe, Djodock and Nyimbe. In each of these villages, inhabitants exploit grubs to a lesser extent and generate earnings of less than XAF 90,000. Generally, income from grub trading is only possible from November to June in the Obout area and from October to March in the Ntoung area. In these periods and even when grubs are no longer available, village inhabitants rely on other activities such as agriculture, fishing, animal husbandry, hunting and gathering of other NTFPs for household income. Overall, agriculture, fishing and grub exploitation are the most common activities practiced across the entire study area (Figure 4).

Grub exploitation represents $21 \%$ of activities practiced in all the villages surveyed (Figure 4). This value is higher than the $15 \%$ observed for all the other of NTFPs gathered for livelihoods in the areas (e.g. bush mango, njansang and palm wine). It is clear that the exploitation of palm weevil grubs plays an important role not only as an alternative source of protein, but also as a valuable potential income source in the areas. This result confirms the work of Arnold et al. (2011) who stated that insects offer a good opportunity for employment and income in developing countries, particularly for the poor in urban and rural areas.
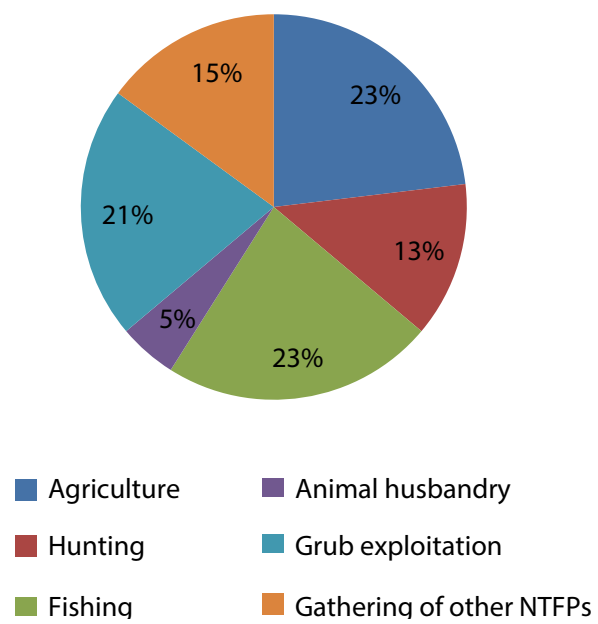

Figure 4. Comparison of grub exploitation with other economic activities in the study areas.

\subsubsection{Preference for grubs as an alternative food source}

Although grub exploiters mainly consume grub specimens that do not meet market criteria, almost everyone in the villages studied consume beetle grubs. The habit of grub consumption in these areas dates back a very long time and a greater number of respondents derive more satisfaction from consuming palm beetle grubs than bushmeat (Figure 5).

However, it is difficult to satisfy household protein needs with grubs, as most local production is destined for trade. 


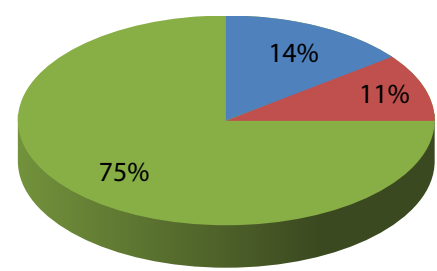

Less appreciated $\quad$ No difference $\quad$ More appreciated

Figure 5. Popularity of grubs compared to bushmeat.

\subsubsection{Social perception and gender implication of weevil grub exploitation}

The exploitation and trade of palm weevil grubs are important activities in all the villages surveyed. The local perception of these activities is similar to that of many other sectors in village economies. Consequently, they are practiced by people of all social classes: poor, middle income and rich (Figure 6).

In addition, this activity is practiced by people of all age groups, including children, teenagers, middleaged people and the elderly (Figure 7 ).

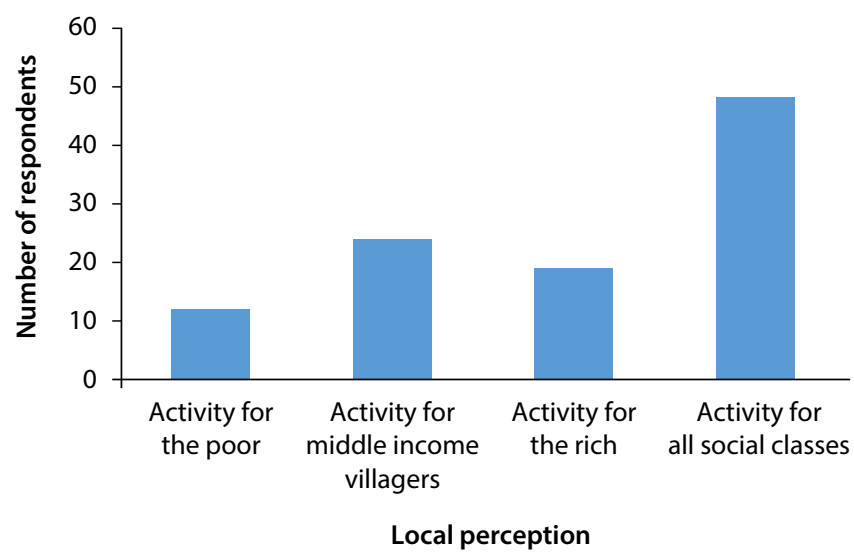

Figure 6. Local perceptions of grub exploitation and trading.
More adolescents and adults are involved in grub exploitation and trading (Figure 7). These age groups are more important in the Obout area where semi-farming is practiced. However, in the Ntoung area, traditional gathering is practiced by older people. Both men and women are involved in grub exploitation and trading in the Ntoung village area, in contrast to the Obout area, where only men are involved in these sectors (Table 15).

Table 15 reveals that all the grub collectors in Obout, Elende and Ebomsi II villages are men. In Ntoung I, Ntoung II and Djodjok, both men and women are involved. The semi-farming system practiced in the Obout area is harder work than the traditional gathering practiced in villages around Ntoung village. Grub exploiters and traders include both married and unmarried men and women. In total, 55 collectors were married (or living together like husband and wife) while 48 were single (Table 16).

Income obtained from grub trading has an important social impact in village communities. In villages such as Obout, Ebomsi II and Elende where grub exploitation is one of the major activities, grub collectors/traders have set up a

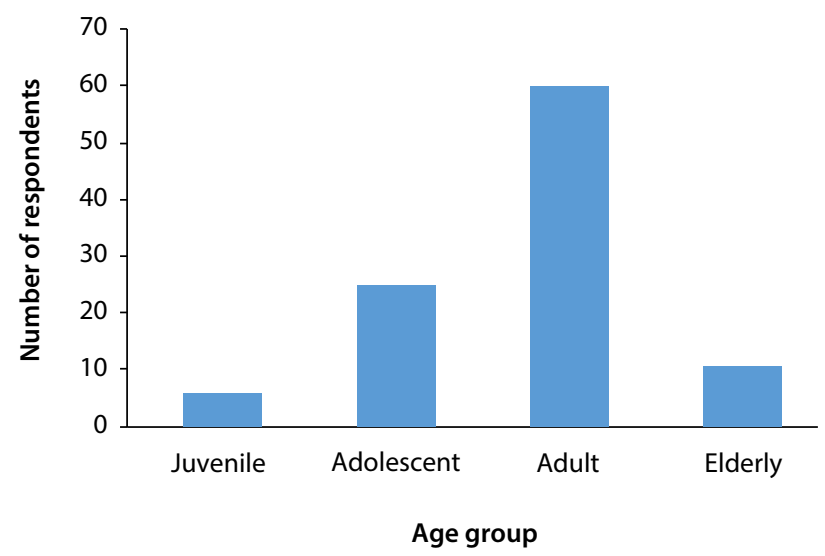

Figure 7. Distribution of grub exploiters by age.

Table 15. Distribution of grub collectors by gender.

\begin{tabular}{lcccccccc}
\hline Sex & Obout & Elende & Ebomsi II & Ntoung I & Ntoung II & Djibe & Djodjok & Nyimbe \\
\hline Men & 17 & 6 & 7 & 20 & 9 & 10 & 17 & 11 \\
Women & 0 & 0 & 0 & 3 & 1 & 0 & 2 & 0 \\
Total & 17 & 6 & 7 & 23 & 10 & 10 & 19 & 11 \\
\hline
\end{tabular}


Table 16. Distribution of respondents by marital status and village.

\begin{tabular}{lccc}
\hline Villages & Married & Single & Total \\
\hline Elende & 2 & 4 & 6 \\
Ebomsi II & 4 & 3 & 7 \\
Obout & 6 & 11 & 17 \\
Ntoung I & 18 & 5 & 23 \\
Ntoung II & 5 & 5 & 10 \\
Ndjibe & 7 & 3 & 10 \\
Djodjok & 8 & 11 & 19 \\
Nymbe & 5 & 6 & 11 \\
Total & $\mathbf{5 5}$ & $\mathbf{4 8}$ & $\mathbf{1 0 3}$ \\
\hline
\end{tabular}

prestigious financial group which bring members together weekly. This group allows members (who are principally grub collectors) to contribute or save at least XAF 10,000 (USD 20) a week. Sometimes, group meetings helps members to harvest grubs from felled raffia stems in the semifarming system. On such occasions, people who are assisted produce large quantities of grubs that they then take to major cities such as Yaoundé or Douala for sale. Income generated from this kind of community-assisted grub exploitation is generally used for purposes such as weddings, housebuilding, purchase of motorcycles, and paying for hospital bills and children's education. Generally, group members take turns to benefit from this initiative. Members who have already benefited from the group help others and who have large quantities of felled trunks usually employ villagers to harvest the grubs. A sum of XAF 2500-3000 (USD 5-6) is paid as a daily wage to those recruited for the harvesting process.

\subsection{Environmental impacts of indigenous harvesting methods}

The exploitation of grubs has a negative impact on the environment, both on raffia palms and populations of wildlife that share the same swampy ecosystem. This is because thousands of raffia stems are felled monthly. However, the semi-farming method is more destructive than traditional gathering method practices where exploited trunks are mostly dead or young raffia stems that have been naturally infested by grubs (Photo 20).
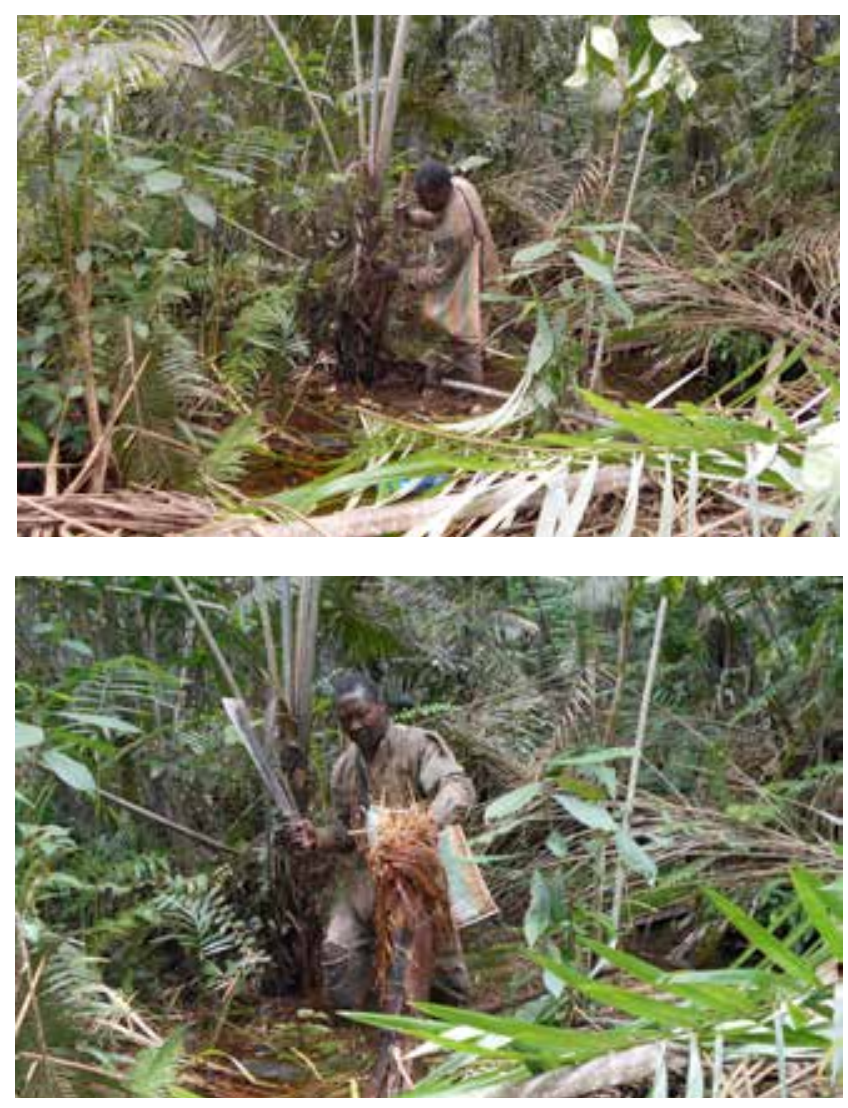

Photo 20. Extraction of grubs from infested young raffia palms using the traditional gathering method.

Nonetheless, it is difficult to determine the actual number of trunks that are exploited in the traditional gathering system, as collectors generally cover vast areas in order to identify raffia stems that have been naturally infested by grubs. In the semi-farming system, healthy mature trunks are cut down for grub production (Photo 21).

In the Obout area, this method has led to the massive destruction of raffia ecosystems. The total number of trunks that could be felled in $2500 \mathrm{~m}^{2}$ plots was estimated during the course of the study (Table 17).

An average of 38 raffia stems, representing $32.2 \%$ of the total population, are felled in an estimated area of $2500 \mathrm{~m}^{2}$ (Table 17). This figure represents the minimum number of raffia stems that can be felled by a single collector during a period of 45 days in the Obout area. However, larger-scale collectors can exploit three to four times this number. Generally, each collector exploits raffia stems every 2 months, and the average total number of raffia trunks felled by a single collector varies between 152 and 601 per year. 

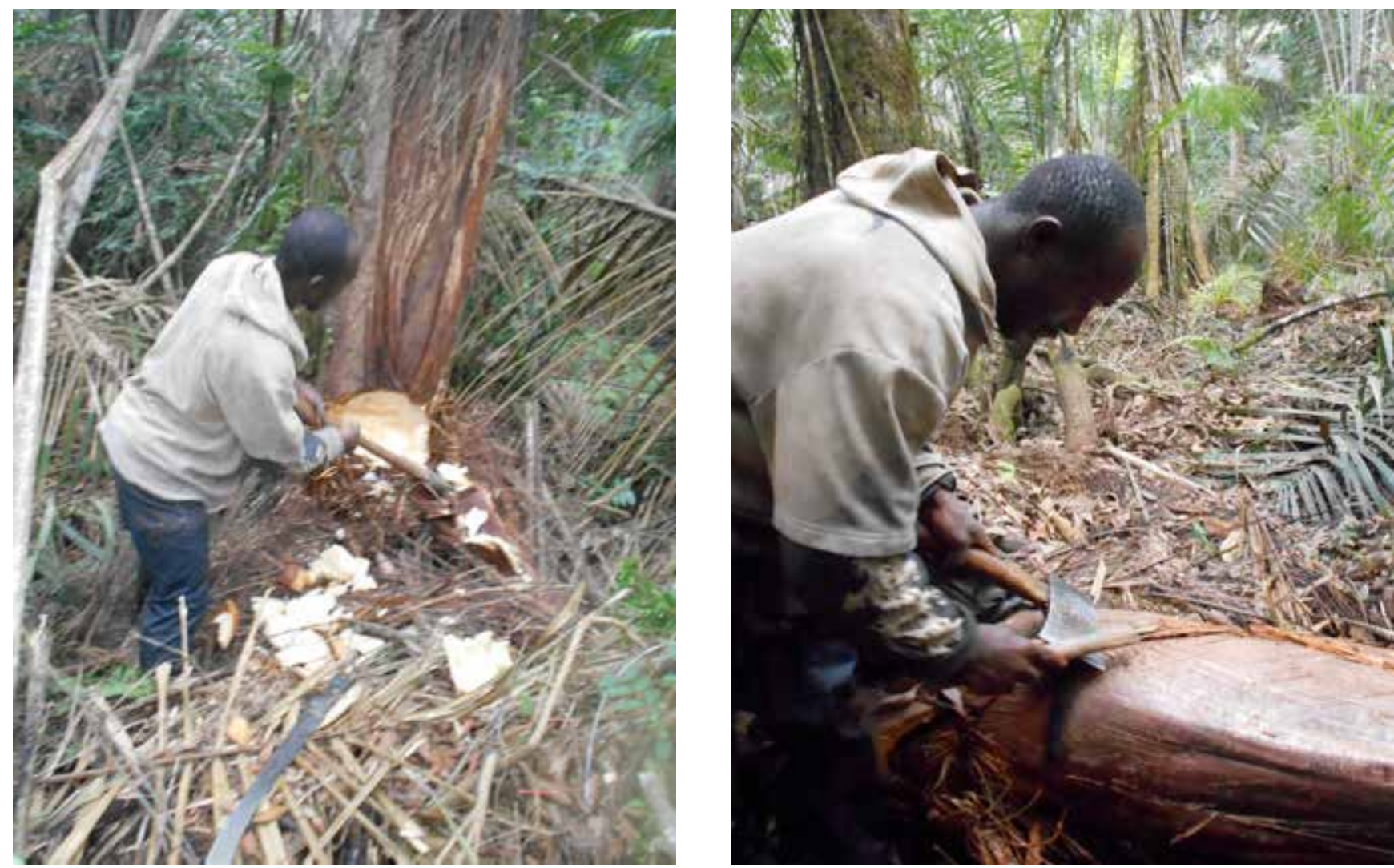

Photo 21. Destruction of raffia ecosystems in the semi-farming method.

Table 17. Number of raffia stems felled per plot.

\begin{tabular}{lccccc}
\hline Number of raffia & Plot 1 & Plot 2 & Plot 3 & Plot 4 & Average \\
\hline Number of adult stems per plot & 120 & 147 & 97 & 109 & 118 \\
Number of adult stems felled & 40 & 56 & 21 & 34 & 38 \\
Percentage of adult stems felled (\%) & 33.33 & 38.09 & 21.65 & 31.19 & 32.20 \\
\hline
\end{tabular}

\subsection{Grub marketing chain}

The commercialization of palm weevil grubs in the two study sites involves direct sales to travelers at the roadside or through middlemen, known locally as bayam-sellam, who buy grubs to resell in big cities such as Yaoundé and Douala or in towns such as Mbalmayo and Abong-Mbang (Photo 22).

Some traders from big cities who cannot get grubs directly from collectors buy from town markets. Business arrangements are largely facilitated by phone calls, generally a day before collectors go to do the harvesting. The market chain for palm weevil grubs is summarized in Figure 8.

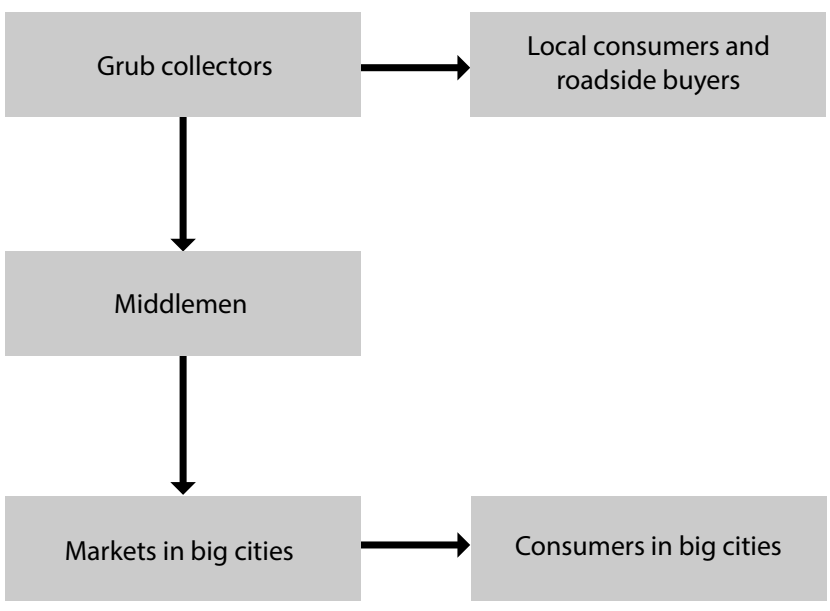

Figure 8. Market chain for palm beetle grubs. 

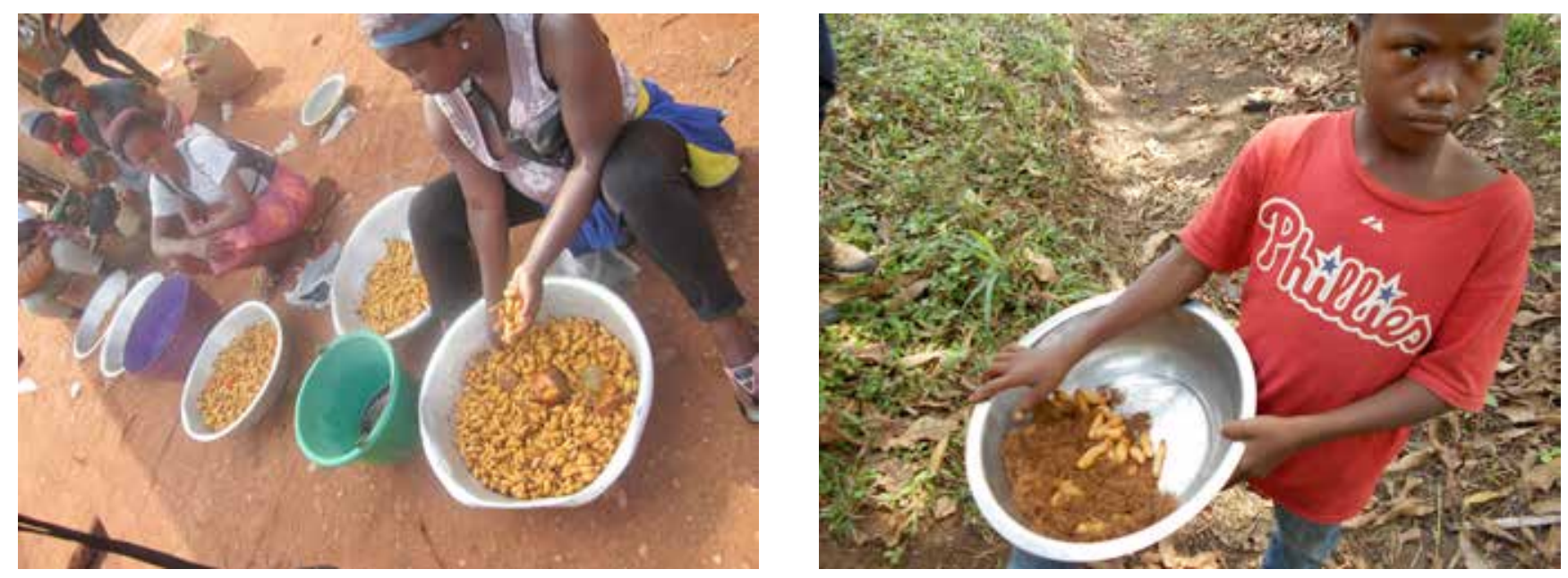

Photo 22. Sales of grubs in an urban market (left) and at roadsides in villages (right).

The rising demand for grubs in recent years has increased market prices at both the local level and in urban cities. In the late 1990s, the price for 12 weevil grubs was XAF 100 (USD 0.20) in most of the villages around the Obout area. Currently the price has increased drastically and the number of grubs sold for XAF 100 has fallen from 12 to 4 individuals. Compared to other sources of protein, a kilogram of weevil grubs is still less expensive than beef without bones, but more expensive than fish and beef with bones (Figure 9).

In cities such as Yaoundé for example, a glass containing an average of 43 grubs is sold at XAF 1500 (USD 3). In some cases, sticks with 3 largesized roasted grubs or 4 small grubs are sold at XAF 100 (USD 0.20) at bus stops and other public places. In a single business trip, a grub trader from the city can buy an average of $50 \mathrm{~kg}$ of grubs around neighboring villages. The estimated value of this quantity of grubs is XAF 133,500 (USD 267), which is shared between the collectors who have contributed to the supply.

\subsection{Grub farming method and productivity of food formulas}

The grub farming method consists of mating adult palm weevils and putting them into boxes containing different food formulas. Plastic boxes were more productive than wooden boxes, probably because it was more difficult to maintain wooden boxes at a temperature favorable for the development of grubs. For three pairs of adult weevils introduced in plastic

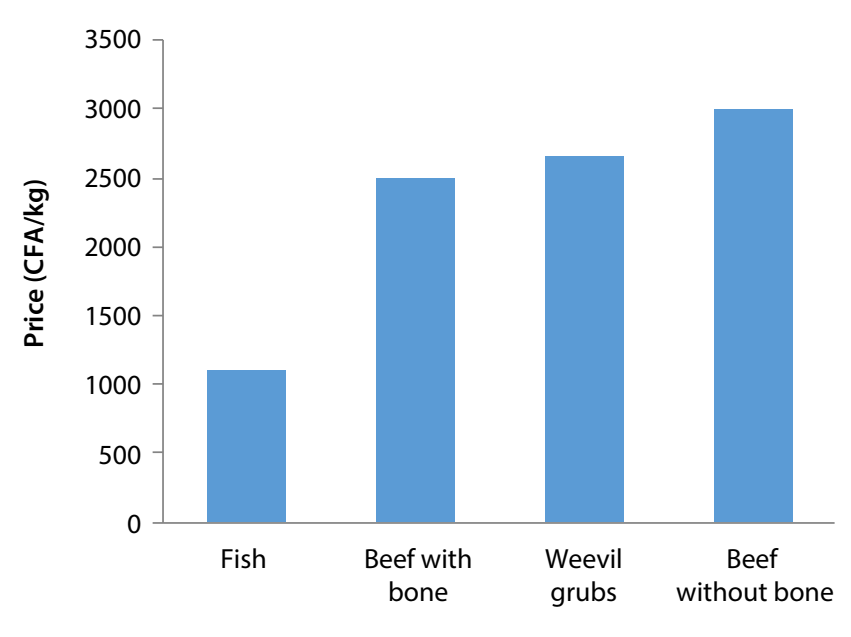

Source of animal protein $(\mathbf{k g})$

Figure 9. Comparison of the per-kilogram prices of grubs and other sources of protein.

boxes, a total of 173 grubs were harvested from three boxes of the experimental farming apparatus containing suitable food formulas (Photo 23).

However, of the four food formulas tested, boxes containing only fresh raffia tissues (OFRT) were the most productive, recording up to 73 weevil grubs per box, with an average production of $69 \pm 5.6$. These values are higher than those of the food formula composed of a mixture of $75 \%$ fresh and $25 \%$ dry raffia (MFDRT1), which recorded an average of 30 grubs, and those with food formula composed of a mixture of $50 \%$ fresh and $50 \%$ dry raffia tissue (MFDRT2), in which only five individual grubs were harvested. The fourth food formula consisted 

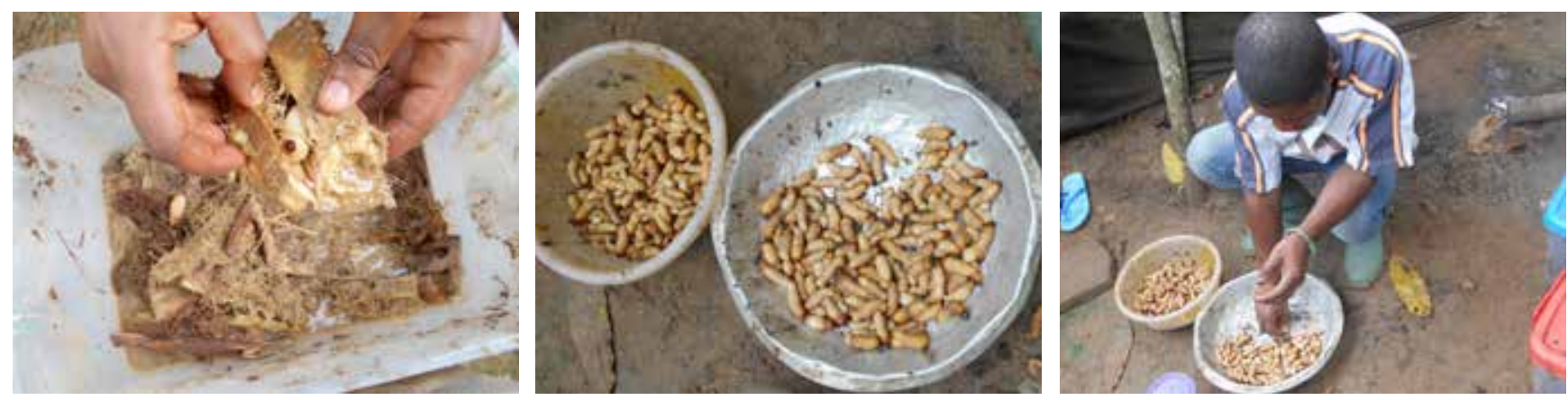

Photo 23. Harvesting of grubs from the experimental farming system.

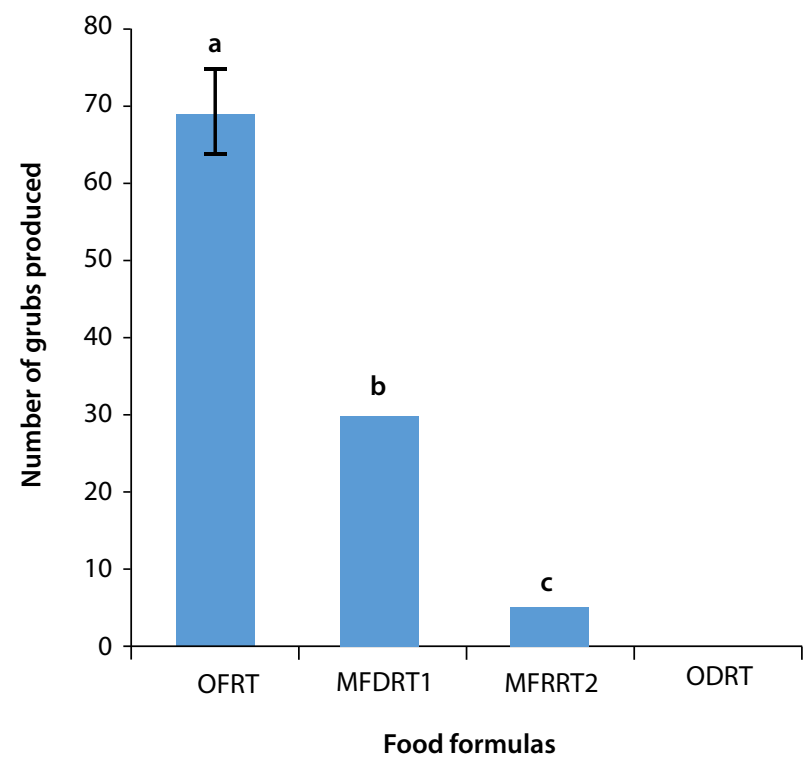

Figure 10. Number of grubs produced per food formula.

of dead raffia tissue (ODRT) and was nonproductive (Figure 10).

A significant difference was observed in the efficiency of the different food formulas (one-way ANOVA: $\left.\mathrm{F}_{1,3}=4.781 \mathrm{e}+31 ; \operatorname{Pr}=2 \mathrm{e}-16\right)$. The productivity of OFRT was significantly higher than that of all the other food formulas (Turkey post hoc test: $\mathrm{p}=$ 0.000). The time period required for the farming process was exactly 30 days (from the collection and coupling of adults to the harvest of grubs). From these results, we can conclude that the productivity of the different food formulas is directly linked to the level of freshness of the raffia tissues (Figure 11).

A linear correlation of 0.93 was observed between the mean production of grubs and the level of freshness of the raffia tissues in the different food formula (i.e. production of OFRT>

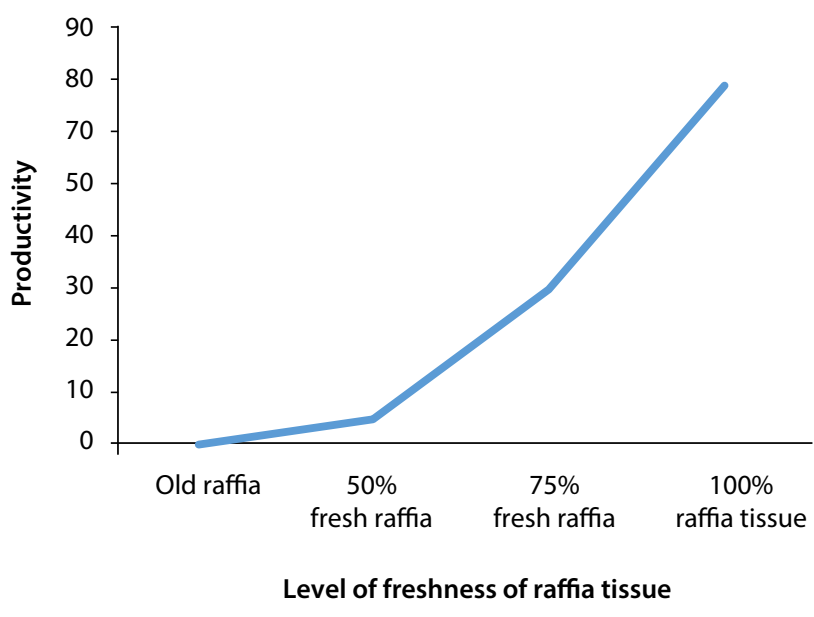

Figure 11. Variation of grub production with the level of freshness of raffia tissue.

MFDRT1>MFDRT2>ODRT). Verifying this observation with T-tests, the correlation was confirmed at $95 \%$ confidence interval $(\mathrm{t}=-5.1082, \mathrm{df}=4$, $\mathrm{p}$-value $=0.006943)$. From this observation, we can conclude that the fresher the raffia tissue, the higher the production of grubs. Although food formulas with old raffia tissues were less productive, they were favorable to the development of a species of grub parasite that could not be identified during the course of this study (Photo 24).

\subsection{Comparison of the production, physiological characteristics and palatability of grubs from the indigenous harvesting and farming systems}

The number of grubs produced by a single box in the grub farming system was higher than the production 


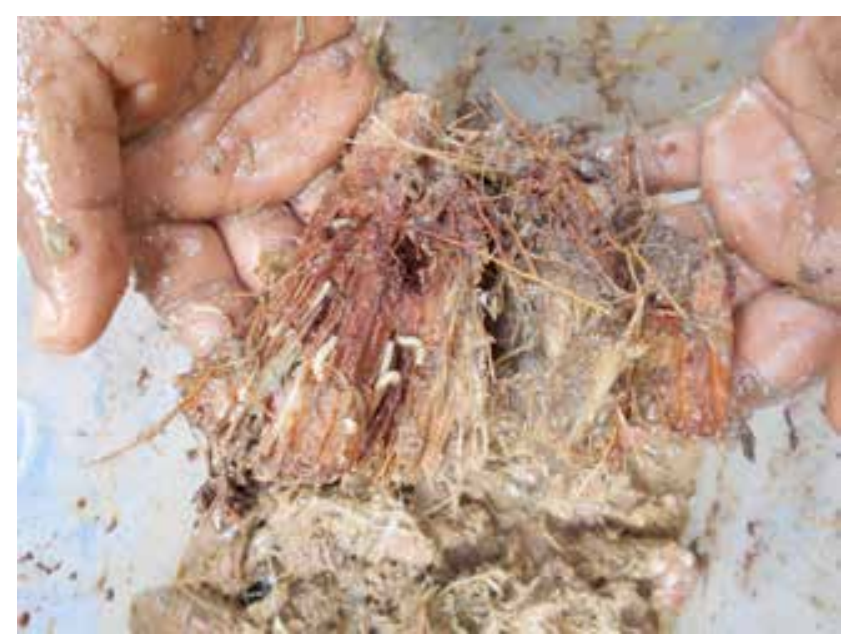

Photo 24. An unidentified species of grub parasite.

per stem of raffia in both the traditional gathering and semi-farming systems. A total of two raffia stems were used as substrate in the three boxes that yielded 173 grubs in the farming system (about $1 / 4$ of a raffia stem was used per box). The average productivity per box containing approximately $1 / 4$ of raffia stem in the farming system was estimated at $69 \pm$ 5.6. A single stem of felled raffia can be used to establish four boxes in the farming system. With an average of 69 individuals per box, a single stem of raffia used as substrate in the boxes will produce a total of 276 grubs. This value is more than five times the maximum productivity of a single stem of raffia in the semi-farming system $(50 \pm 10.1)$ and nearly eight times that of the traditional gathering method $(35 \pm 13.2)$. The difference in the estimated productivity per stem of raffia for the three production systems is shown in Figure 12.

Figure 12 shows that the grub productivity of a single stem of raffia is highest in the experimental farming system than in the semi-farming system or through traditional gathering. If the farming system is well managed, grubs would be produced to meet market demands and ensure year-round regularity of supply. The number of raffia stems that would be exploited for grub production would be reduced significantly, thereby assuring the survival and sustainability of the raffia ecosystem.

Although the period from felling raffia stems to when grubs are mature enough for harvest is estimated at 25 to 30 days for both the semi-farming and the farming systems, the number of working days required for the production of the same quantity of grubs is higher for the two indigenous methods than

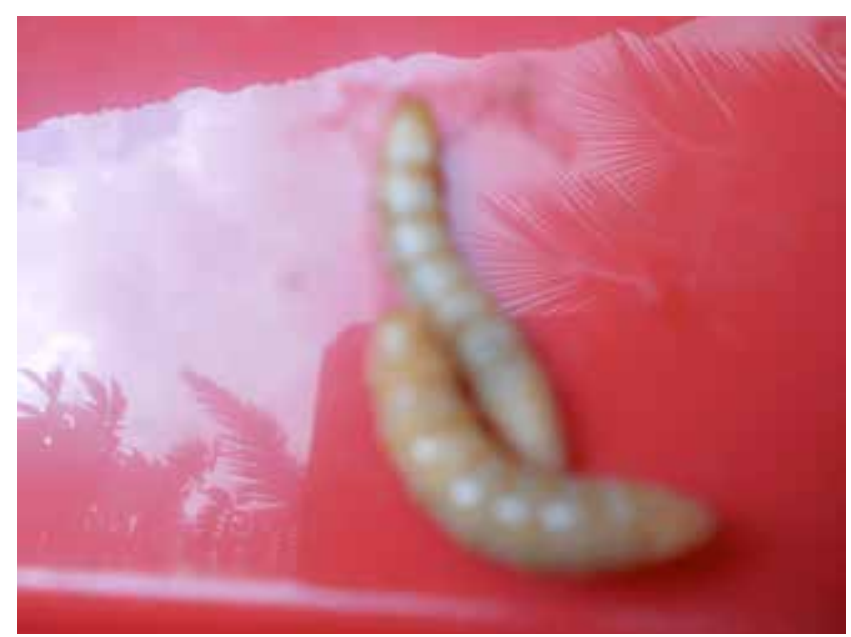

using the farming system. With traditional gathering, collectors go to the forest for many days in order to harvest a reasonable quantity of grubs. In the semifarming method, collectors spend many days in the forest to cut and prepare raffia stems. From the second week, each of the prepared stems is visited twice a week in order to verify and eventually control the colonization process. The return per working day is therefore higher in the farming system than in the other methods of harvesting. In addition, the quality of grubs exploited and those produced from the farming system had the same physiological characteristics and palatability as those collected from the wild (Table 18).

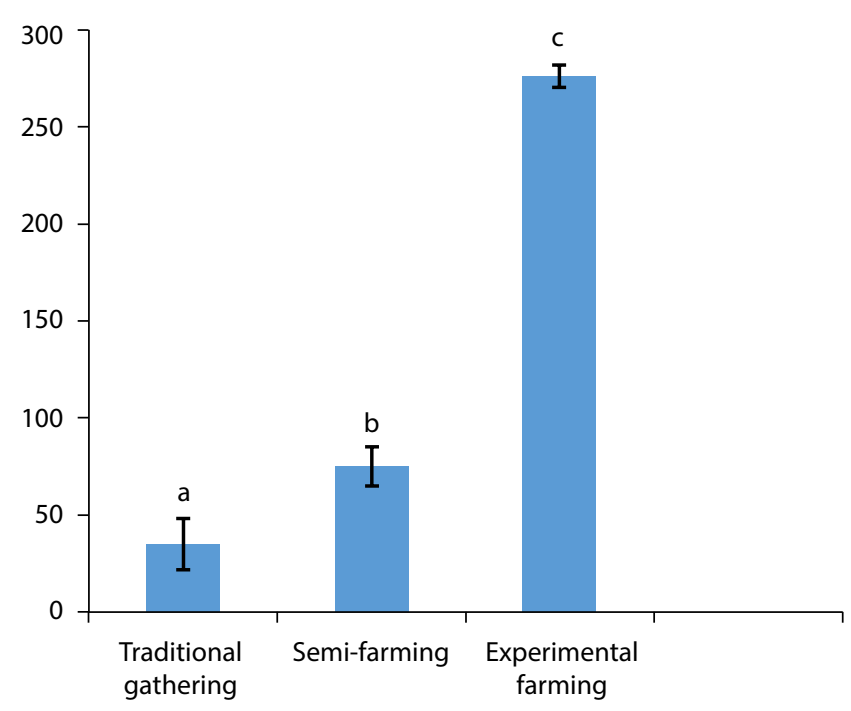

Figure 12. Comparison of grub productivity per stem of raffia exploited in the different production systems. 
Table 18. Physiological characteristics and palatability of wild and farmed grubs.

\begin{tabular}{|c|c|c|c|c|c|}
\hline \multirow[t]{2}{*}{$\begin{array}{l}\text { Production } \\
\text { system }\end{array}$} & \multirow[t]{2}{*}{ Quantity of raffia used } & \multirow[t]{2}{*}{ Productivity } & \multicolumn{2}{|c|}{$\begin{array}{l}\text { Grubs' physiological } \\
\text { characteristics }\end{array}$} & \multirow[t]{2}{*}{ Palatability } \\
\hline & & & Color & Length & \\
\hline $\begin{array}{l}\text { Traditional } \\
\text { gathering }\end{array}$ & 1 raffia stem of 2 to $3 \mathrm{~m}$ & 35 grubs & Whitish yellow & $5-6 \mathrm{~cm}$ & Sweet fatty taste \\
\hline Semi-farming & 1 raffia stem of 2 to $4 \mathrm{~m}$ & 50 grubs & Whitish yellow & $5-6 \mathrm{~cm}$ & Sweet fatty taste \\
\hline Farming & Less than $1 / 4$ stem & 69 grubs & Whitish yellow & $5-6 \mathrm{~cm}$ & Sweet fatty taste \\
\hline
\end{tabular}

These characteristics were confirmed by local people who assisted in the harvest, preparation and sampling (tasting) of grubs from the boxes in the experimental farming system (Photo 25).

The cooked grubs from the experimental farming system had the same taste as those collected from raffia in the wild. This system of production has a number of advantages over the two indigenous harvesting systems.

- It is more productive than all the indigenous harvesting methods;
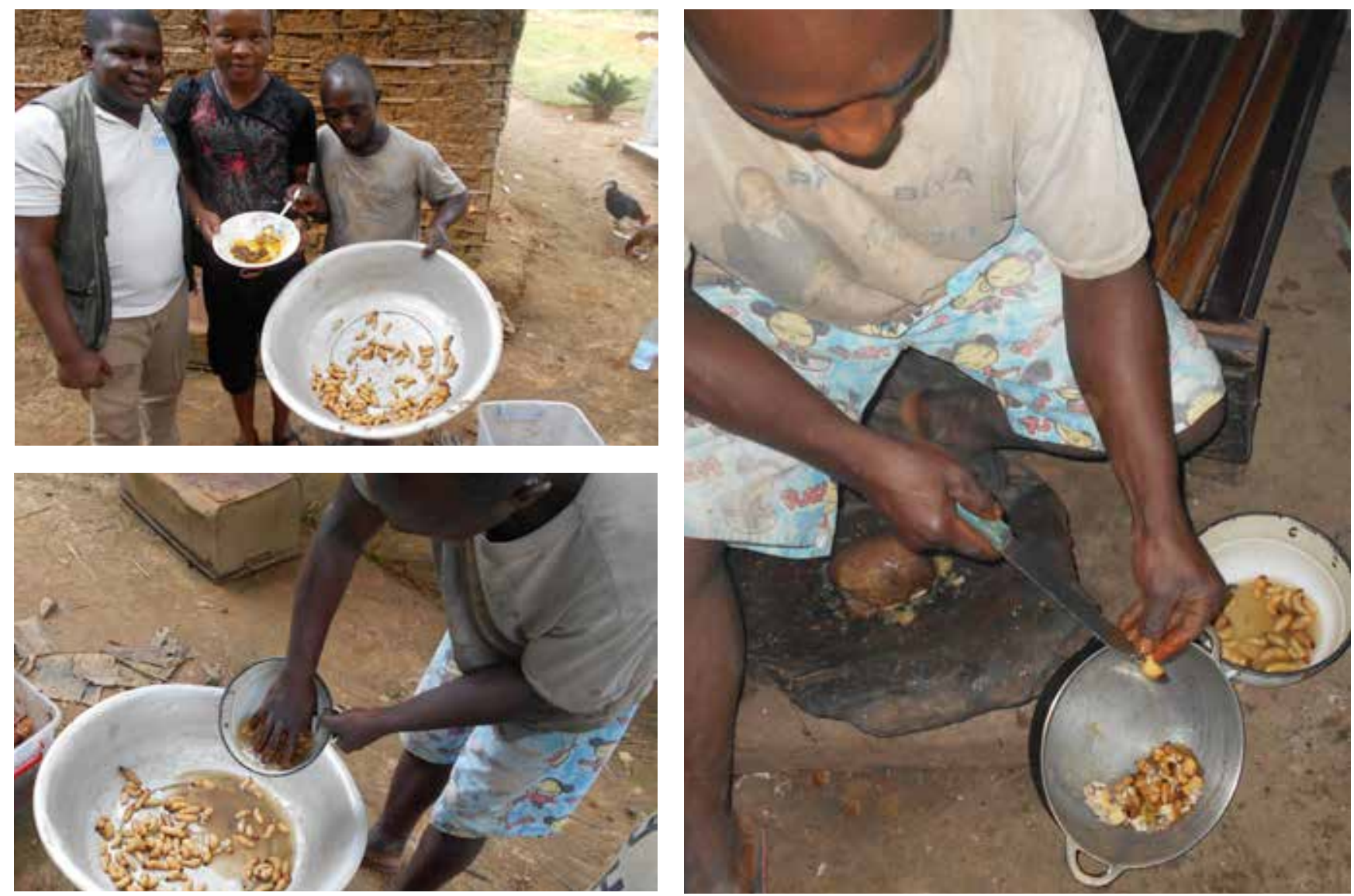

- It ensures year-round production of grubs, allowing a regular supply of grubs in both the dry and rainy seasons.

- It prevents massive destruction of raffia ecosystems, as it involves the use of smaller amounts of raffia tissue.

- It is less labor intensive and does not require collectors to spend hours and days in the forest to collect the grubs.

- It is less risky than the indigenous methods (which include accidents and snakebites).

Photo 25. Preparation of farmed grubs for sampling. 


\section{Conclusion and recommendations}

The exploitation and trade of palm weevil grubs is an important source of livelihood in the Obout and Ntoung areas. Many local people depend on this resource for food, income and medicine. The market prices and demand for this resource are increasing, providing new market opportunities. Due to the high economic value of this resource, the exploitation of grubs is commonly practiced and considered to be more important than hunting, fishing and animal husbandry. However, the exploitation of this resource from the wild is characterized by a low productivity, irregular supply and negative environmental impacts. The newly developed grub farming system is particularly sustainable, highly productive and consumes raffia stems than the traditional gathering or semi-farming systems. Promotion of this farming method will guarantee farmers sustainable and continuous production of grubs and enhances the contribution of this resource to local livelihoods and participatory forestry.
From the results obtained in this study, the following recommendations can be made to the different actors of the palm weevil grub sector:

\section{a) Cameroon Government}

- Promote palm weevil grubs as an important NTFP for livelihood improvement and to enhance participatory forestry and communitybased conservation

- Promote sustainable exploitation and farming of palm weevil grubs as an alternative source of protein in the study area and in Cameroon

- Define a legal framework for the exploitation and trade of palm weevil grubs.

\section{b) Researchers}

- Identify the species of parasite observed during the experimental grub farming system

- Develop ways in which grubs can be processed to produce globally accepted human food and feed

- Improve and disseminate the newly developed grub farming method. 


\section{References}

Aboubacar AC, Dugué P and Foresta H. 2012. Transformation des mosaïques de forêtsavane par des pratiques agroforestières en Afrique subsaharienne (Guinée et Cameroun), Cybergeo : European Journal of Geography, Environnement, Nature, Paysage, document 627 URL: http://cybergeo.revues.org/25588; DOI: 10.4000/cybergeo. 25588

Arnold JEM and Ruiz Pérez M. 2001. Can nontimber forest products match tropical forest conservation and development objectives? Ecological Economics 39(3):437-47.

Arnold, JEM, Powell B, Shanley P and Sunderland TCH. 2011. Editorial: Forests, biodiversity and food security. International Forestry Review 13(3):259-264.

Asibey EAO and Child G. 1991. Wildlife management for rural development in subSaharan Africa. Nature et Faune 7:36-47.

Balinga P. 2003. Contribution des insectes à la sécurité alimentaire. Rapport FAO, département des forêts.

Barreteau D. 1999. Les Mofu-Gudur et leurs criquets. In L'homme et l'animal dans le bassin du lac Tchad. Actes du colloque du réseau MegaTchad, Orleans 15-17 octobre 1997. Baroin $\mathrm{C}$ and Boutrais J, eds. Editions IRD (Institut de Recherche pour le Développement), Collection Colloques et Séminaires, no. 00/354. Université Nanterre, Paris. 133-69.

Belcher BM, Ruiz Pérez M and Achdiawan R. 2005. Global patterns and trends in the use and management of commercial NTFPs: Implications for livelihoods and conservation. World Development 33(9):

Benson T. 2004. Africa's food and nutrition security situation: Where are we and how did we get here. 2020 Discussion Paper 37. Washington, D.C. USA: International Food Policy Research Institute (IFPRI).

Bodenheimer FS. 1951. Insects as Human Food. The Hague: W. Junk.

[COMIFAC] The Central African Forests Commission. 2008. Highlights from the state of the forest. Accessed 20 October 2014. http:// www.cbfp.org and http://www.comifac.org/

De Foliart GR. 1997. An overview of the role of edible insects in preserving biodiversity. Ecology of Food and Nutrition 36:109-32.
De Foliart G.R. 1992. Insects as human food. Crop Protection, 5 (11): 395-399.

De Lisle M. 1944. Note sur la faune coléoptérologique du Cameroun. Bulletin de la Société d'Etudes Camerounaises 5:55-71.

Dounias E. 1999. L'exploitation méconnue d'une ressource connue: La récolte des larves comestibles de charançons dans les palmiers raphia au Cameroun. Présentation orale.

Dounias E. 1999. L'exploitation méconnue d'une ressource connue: La récolte des larves comestibles de charançons dans les palmiers raphia au Cameroun. Présentation orale.

Dreyer JJ, Wehmeyer AS. 1982. On the nutritive value of mopanie worms. South African Journal of Science 78: 33-35.

Ekpo EK and Onigbinde OA. 2005. Nutritional Potentials of the Larva of Rhynchophorusphoenicis (F). Pakistan Journal of Nutrition 4(5):287-90.

Elemo BO, Elemo GN, Makinde MA and Erukainure OL. 2011. Chemical evaluation of African palm weevil, Rhychophorus phoenicis, larvae as a food source. Journal of Insect Science 11:146

Fa JE, Yuste JEG and Castelo R. 2000. Bushmeat markets on Bioko Island as a measure of hunting pressure. Conservation Biology 14:1602-13.

[FAO] Food and Agriculture Organization of the United Nations. 1995. Non-wood forest products for rural income and sustainable forestry. Non-wood forest products 7. Rome: FAO.

[FAO]/[WHO] Food and Agriculture Organization of the United Nations/ World Health Organization. 1973. Energy and protein requirements: Report of a joint FAO/WHO ad hoc expert committee. [FAO] Nutrition Meetings Report Series No. 52. WHO Technical Report Series No. 522.

Gries G, Gries R, Perez AL, Oehlschlager AC, Gonzalez IM, Pierce HD, Kouda I, Zebeyou M and Nanou N. 1993. Aggregation pheromone of the African palm weevil, Rhynchophorus phoenicis F. Naturwissenschaflen 80:90-1.

Jiofack T, Guedje N, Ayissi I, Fokunang C, Usongo L and Nkongmeneck B. 2010. Upper Nyong valley forest in Cameroon: Ethnobotanical uses and implications for biodiversity conservation. 
International Journal of Biodiversity and Conservation 2(11):370-81.

López C and Shanley P. 2004 Riches of the forest: For health, life and spirit in Africa. Bogor, Indonesia: Center for International Forestry Research (CIFOR).

Malaisse F. 1997. Se nourrir en forêt claire africaine. Approche écologique et nutritionnelle. Les Presses agronomiques de Gembloux. Gembloux, Belgique.

Mariau D, Chenon R, Julia JF and Philippe R. 1981. Oil palm and coconut pests in West Africa. Oleagineux 36(4):169-227.

Merle. 1958. Des chenilles comestibles. Notes Africaines 77:20-3.

Muafor FJ, Levang P and Le Gall P. 2014. A crispy delicacy: Augosoma beetle as alternative source of protein in east Cameroon. International Journal of Biodiversity: Article ID 214071, 7 pages.

Muafor FJ, Levang, P and Le Gall P. 2012. Making a living out of forest insects: Beetles as income source in southwest Cameroon. International Forestry Review 14(3):314-25.

Ndoye O, Ruiz-Perez M and Eyebe A. 1997. The markets of non-timber forest products in the humid forest zone of Cameroon. Londres, Grande Bretagne, Overseas Development Institute, Rural Development Forestry Network, ODI Network Paper 22c.

Ogbuagu MN, Ohondu I and Nwigwe C. 2011. Fatty acid and amino acid profiles of the larva of raffia palm weevil: Rhynchophorus phoenicis. Pacific Journal of Science and Technology 12(2):392-400.

Pearson D. 1976. The chemical analysis of foods, 7 th edition. pp. 488-497. Churchill Livingstone: Edinburgh, U.K. 572p.

Pimentel D, McNair M, Black L, Pimentel M and Kamil J. 1997. Value of forests to world food security. Human Ecology 25:91-120.

Seignobos C, Deguine JP and Aberlenc HP. 1996. Les Mofu et leurs insectes. Journal d'Agriculture Traditionnelle et de Botanique Appliquée 28:125-87.
Stack J, Dorward A, Gondo T, Frost P, Taylor F and Kurebgaseka N. 2003. Mopane worm utilization and rural livelihoods in Southern Africa. CIFOR Livelihood Conference, Bonn.

Tambe TJ, Riolo P, Okolle NJ, Isidoro N, Fanciulli PP and Dallai R. 2013. Sexual size differences and color polymorphism of Rhynchophorus phoenicis in the Southwest region of Cameroon. Bulletin of Insectology 66(1):153-9.

Tessmann G. 1913. Die Pangwe: völkerkundliche Monographie eines westafrikanischen Negerstammes; Ergebnisse der Lu"becker Pangweexpedition 1907-1909 und früherer

Forschungen 1904-1907, Von Günter Tessmann. E. Wasmuth, A.-G. Berlin.

Tieguhong JC and Zwolinski J. 2009. Supplies of bushmeat for livelihoods in logging towns in the Congo Basin. Journal of Horticulture and Forestry $1(5)$.

Van Huis A, Van Itterbeeck J, Klunder H, Mertens E, Halloran A, Muir G and Vantomme P. 2013. Edible insects: Future prospects for food and feed security. FAO Forestry Paper No. 171. Rome: FAO.

Vantomme P, Göhler D and N'deckere-Ziangba F. 2004. Contribution of forest insects to food security and forest conservation: The example of caterpillars in Central Africa. ODI Wildlife Policy Briefing No. 3. Http://www.odi-bushmeat.org/wildlife_ policy_briefs.htm

Wilkie DS and Carpenter J. 2000. The potential role of safari hunting as a source of revenue for protected areas in the Congo Basin. Oryx 33:340-5.

Womeni HM, Tiencheu B, Linder M, Nabayo CME, Tenyang N, Mbiapo TF, Villeneuve P, Fanni J and Parmentier M. 2012. Nutritional value and effect of cooking, drying and storage process on some functional properties of Rhynchophorus phoenicis. International Journal of Life Science and Pharma Research 2(3):203-19. 

CIFOR Working Papers contain preliminary or advance research results on tropical forest issues that need to be published in a timely manner to inform and promote discussion. This content has been internally reviewed but has not undergone external peer review.

The larvae (grubs) of the African palm weevil are consumed by the majority of inhabitants of the Congo Basin. These larvae are extremely rich in essential food nutrients; they contain proteins, carbohydrates, fats and energy values comparable to those of beef and fish. They are also an excellent source of a range of minerals and vitamins. The exploitation and trade of weevil grubs is an important source of income for forest dependent communities in the Congo Basin. These grubs are currently harvested from raffia and palm stems in the wild. This study evaluates the sustainability of indigenous harvesting techniques, and investigates ways in which these insect resources could be farmed in Obout and Ntoung village areas. Results show that grubs are harvested by collecting them from naturally infested raffia stems (the traditional collection method) or by cutting and preparing healthy raffia stems for grub production (the semi-farming method). Both methods are unsustainable, as thousands of raffia stems are cut down on a monthly basis. To address this situation, a grub farming system has been developed within the course of this study. It has proved to be more productive and sustainable than both the traditional collection and the semi-farming methods. This farming system could be used to produce grubs at any time of the year, thereby providing an opportunity for year-round availability of these nutritious insects, while securing their place as an important alternative to protein and a valuable income source in Cameroon.

\begin{tabular}{|c|c|c|}
\hline CGIAR & $\begin{array}{l}\text { RESEARCH } \\
\text { PROGRAM ON } \\
\text { Forests, Trees and } \\
\text { Agroforestry }\end{array}$ & $\begin{array}{l}\text { This research was carried out by CIFOR as part of the CGIAR Research Program on Forests, Trees } \\
\text { and Agroforestry (CRP-FTA). This collaborative program aims to enhance the management and } \\
\text { use of forests, agroforestry and tree genetic resources across the landscape from forests to farms. } \\
\text { CIFOR leads CRP-FTA in partnership with Bioversity International, CATIE, CIRAD, the International } \\
\text { Center for Tropical Agriculture and the World Agroforestry Centre. }\end{array}$ \\
\hline
\end{tabular}
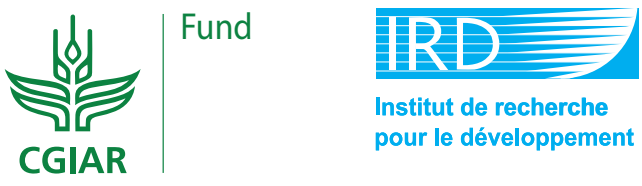

Institut de recherche pour le développement 